\title{
Review of Deaths and Behavior of Large Birds of Prey on Power Grid Facilities in Tatarstan and Udmurtia (Russia), Problems of Modernization of 6-10 kV Overhead Power Lines ОБЗОР ФАКТОВ ГИБЕЛИ И ПОВЕДЕНИЯ КРУПНЫХ ХИЩНЫХ
ПТИЦ НА ЭЛЕКТРОСЕТЕВЫХ УСТАНОВКАХ В ТАТАРСТАНЕ
И УДМУРТИИ (РОССИЯ), ПРОБЛЕМЫ МОДЕРНИЗАЦИИ
ВОЗДУШНЫХ ЛИНИЙ ЭЛЕКТРОПЕРЕДАЧИ 6-10 КВ
}

Bekmansurov R.H. (Kazan Federal University, Elabuga Institute; National Park "Nizhnyaya Kama", Elabuga, Republic of Tatarstan, Russia)

Бекмансуров Р.Х. (Казанский федеральный университет, Елабужский институт; ФГБУ Национальный парк «Нижняя Кама», Елабуга, Республика Татарстан, Россия)

\author{
Контакт: \\ Ринур Бекмансуров \\ Казанский \\ ферееральный \\ университет \\ Елабужский институт \\ Национальный парк \\ «Нижняя Кама» \\ Россия 423607 \\ Республика Татарстан \\ Елабуга \\ ул. Казанская, 89 \\ тел.: +7855 5775455 \\ rinur@yandex.ru
}

\section{Contact:}

Rinur Bekmansurov

Kazan Federal University,

Elabuga Institute

National Park

"Nizhnyaya Kama"

Kazaknskaya str., 89

Elabuga

Republic of Tatarstan

Russia 423600

tel.: +7855 5775455

rinur@yandex.ru

\section{Резюме}

В сообшении проанализированы ранее опубликованные в литературе фракты гибели крупных хишных птиц в электросетевой среде Татарстана с 2012 г. и дополнительные, выявленные с 2019 г., в том числе на территории соседне-

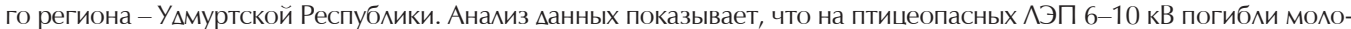

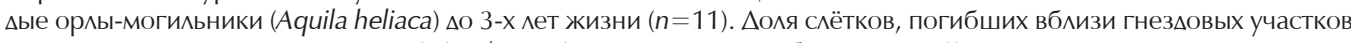
после вылета из гнёзд, составила $(81,8 \%, n=9)$; одна птица погибла на второй год жизни и одна - 3-х летнего

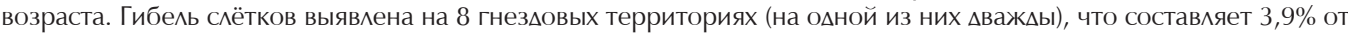
всех известных в Татарстане гнездовых территорий орла-могильника к окончанию 2021 г. (n=205) и около 7,2\% от 111 гнездовых территорий в 16 административных районах юго-востока Татарстана, гАе ведётся нефртедобыча. Из 6 слётков, мля которых был установлен временной интервал гибели, во второй половине августа погибли 2 орла, и также по 2 орла погибли в первой и второй половинах сентября. Аистанции от точно установленных гнёзА $\Delta$ о места гибели слётков составили от 0,26 до 11,7 км, в среднем 2,56 км ( $n=7)$. В 57,1 \% гибель произошла на расстоянии менее 1 км (от 260 до 600 м), в 28,6 \% - на дистанции от 2 до 3 км. Наблюдения за поведением орлов-мо-

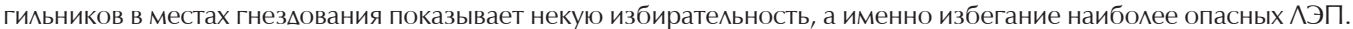
Продолжается аАаптация орлов-могильников к электросетевой среде - обнаружены 3 новых гнездовых участка на опорах высоковольтных ^ЭП. Выявлены 2 случая гибели молодых орланов-белохвостов (Haliaeetus albicilla) на птицеопасных ^ЭП 6-10 кВ в глубине ^есных массивов на узких лесных просеках в Татарстане и УАмуртии, а

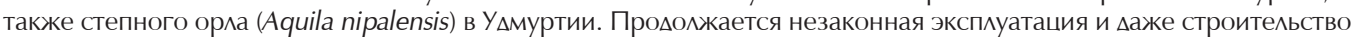
новых птицеопасных ^ЭП 6-10 кВ. Несмотря на проводимые меры по зашите птиц от гибели в электросетевой среде, темпы и качество этих мероприятий таковы, что в ближайшем будушем АЭП будут, как и сейчас, негативно влиять на орланов и орлов в нативной области.

КАючевые слова: хишные птицы, орлан-белохвост, Haliaeetus albicilla, орёл-могильник, Aquila heliaca, пораже-

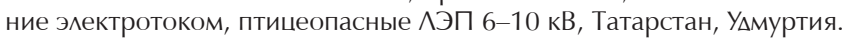

Поступима в редакцию: 20.12.2021 г. Принята к публикации: 28.12.2021 г.

\section{Abstract}

The report analyzes the deaths of large birds of prey on power grid facilities of Tatarstan previously published in the literature since 2012 and additional ones, identified since 2019, including in the neighboring region - Udmurtian Republic. Analysis of the data shows that immature Imperial Eagles (Aquila heliaca) up to 3 years old $(n=11)$ died on the 6-10 kV power lines dangerous for birds. The percentage of fledglings that died near breeding territories after leaving their nests was $81.8 \%(n=9)$; one bird died in its second year of life and one bird died in its third year. The death of fledglings was identified in 8 breeding areas (in one of them twice), which is $3.9 \%$ of all known breeding areas of the Imperial Eagle in Tatarstan by the end of $2021(n=205)$ and about $7.2 \%$ of 111 breeding areas in 16 administrative districts of southeastern Tatarstan where oil production is taking place. Two out of six fledglings, for which a time interval of death was established, died in the second half of August, and 2 eagles also died in the first and second halves of September. Distances from precisely known nests to locations where the fledglings died ranged from 0.26 to $11.7 \mathrm{~km}$, $2.56 \mathrm{~km}$ on average $(n=7)$. In $57.1 \%$ of cases deaths occurred at distances less than $1 \mathrm{~km}$ (from 260 to $600 \mathrm{~m}$ ), and in $28.6 \%$ of cases at distances from 2 to $3 \mathrm{~km}$. Observations of the behavior of Imperial Eagles in breeding grounds show a certain selectivity, namely avoidance of the most dangerous power lines. Adaptation of Imperial Eagles to the electric grid environment continues -3 new breeding territories on the electric poles of high-voltage power lines were found. Two cases of death of immature White-Tailed Eagles (Haliaeetus albicilla) were identified on 6-10 kV power lines dangerous for birds deep in the forestland on narrow forest cleared strips in Tatarstan and Udmurtia, as well as the Steppe Eagle (Aquila nipalensis) in Udmurtia. Illegal exploitation and even construction of new 6-10 kV power lines dangerous for birds continues. Despite the measures taken to protect birds from death in the electric grid environment, the rate and quality of these measures are such that in the near future power lines will have a negative impact on eagles in the native area as they do now.

Keywords: birds of prey, White-Tailed Eagle, Haliaeetus albicilla, Imperial Eagle, Aquila heliaca, electrocution, transmission lines 6-10 kV dangerous for birds, Tatarstan, Udmurtia.

Received: 20/12/2021. Accepted: 28/12/2021. 


\section{Введение}

Проблема гибели хишных птиц на возАушных миниях электропередачи (^ЭП) имеет обшемировые масштабы (Lehman et al., 2007; Prinsen et al., 2011; Loss et al., 2014), и Россия не является исключением (Пестов, 2005; Карякин, 2012; Салтыков, 2014). В Республике Татарстан проблема

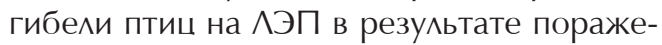
ния электротоком была идентиорицирована в 1981 г. (Салтыков, 1998; 1999; 2000), и только с конца первого Аесятилетия XXI века решению этой проблемы стало уде^яться особое внимание (Бекмансуров и мр., 2012b; Бекмансуров, 2012; 2013). Однако взаимодействие хишных птиц и объектов электросетевого комплекса не всегла несёт угрозу жизни птицам. Многие виды, в том числе орлы, осваивают АЭП в качестве присаь, улучшая шансы на охоту в открытой местности, а также используют их как гнездовые субстраты, более безопасные и долговечные, чем деревья (Карякин, 2008). Не обошёл процесс освоения орлами АЭП и Татарстан - орёл-могильник (Aquila heliaca) ста^ гнезьиться на опорах высоковольтных ^ЭП на юго-востоке Татарстана в самой плотной гнездовой группировке этого вила в Татарии (Бекмансуров, 2015).

Изучение гибели и поведения птиц на электросетевых установках, а также стимумирование модернизации АЭП среднего напряжения 6-10 кВ, которые по своим конструктивным особенностям являются птицеопасными, осушествлялось в ходе ряда проектов, основной задачей которых был мониторинг гнезАовых группировок крупных хишных птиц в Республике Татарстан. Эти проекты велись непрерывно с 2011 года. После 2011 г. не удалось организовать регулярное обследование АЭП с целью выяснения масштабов гибели на них орланов-белохвостов (Haliaeetus albicilla) и орлов в нативной области, тем не менее, собранные попутно фракты представляют интерес. Определённая инорормация о гибели орлов получена в результате мечения птенцов цветными кольцами и GPS/GSM-трекерами. Значительную инорормацию привнесло взаимодействие с гражданским населением, заинтересованным в охране природы.

В Аанном сообшении проанализированы ранее опубликованные в литературе фракты гибели крупных хишных птиц в электросетевой среде Татарстана с 2012 г. и Аополнительные - выявленные с 2019 года, в том числе на территории соседнего региона в УАмуртской Республике.

\section{Introduction}

The problem of deaths of birds of prey on overhead power lines is a worldwide problem (Lehman et al., 2007; Prinsen et al., 2011; Loss et al., 2014), and Russia is no exception (Pestov, 2005; Karyakin, 2012; Saltykov, 2014). In the Republic of Tatarstan the problem of birds electrocution on power lines was identified in 1981 (Saltykov, 1998; 1999; 2000), and only since the end of the first decade of the XXI century special attention has been paid to this problem (Bekmansurov et al., 2012b; Bekmansurov, 2012; 2013). However, the interaction between birds of prey and power grid facilities is not always lifethreatening for birds. Many species, including eagles, develop power lines as perching sites, improving their chances of hunting in the open ground, as well as using them as nesting substrates that are safer and more long-standing than trees (Karyakin, 2008). Tatarstan was also involved in the development of power lines by eagles - the Imperial Eagle (Aquila heliaca) began to nest on the electric poles of high-voltage power lines in the southeast of Tatarstan in the densest breeding group of this species in Tatarstan (Bekmansurov, 2015).

The study of bird mortality and behavior on electric grid facilities and stimulation of 6-10 kV medium-voltage power lines modernization has been carried out since 2011 during several projects implementation, the main task of which was monitoring of breeding groups of large birds of prey in the Republic of Tatarstan. Certain information on eagle deaths was obtained as a result of tagging nestlings with colored rings and GPS/GSM trackers. Significant information was brought by interaction with civilians interested in nature conservation.

This report gives both previously published deaths of large birds of prey in Tatarstan power grid facilities since 2012 and those identified since 2019, including in the neighboring region, the Udmurtian Republic.

Observations of the behavior of eagles in breeding grounds also show a certain selectivity, namely avoidance of the most dangerous power lines. In addition, new facts of eagles nesting on electric poles of high-voltage power lines were revealed.

\section{Materials and methods}

In order to find dead eagles, the electric poles of 6-10 kV medium-voltage power lines and the area under them were examined mostly only along the route of the expedition vehicle, or selective inspections of individual sections of power lines were made. 
Наблюдения за поведением орлов в местах гнездования также показывают некую избирательность, а именно избегание наиболее опасных АЭП. Аополнительно выявмены новые фракты гнездования орлов на

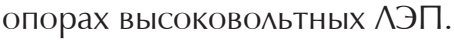

\section{Материалы и методы}

Птицеопасными воздушными миниями электропередачи (^ЭП) признаны минии среднего напряжения 6-10 кВ, которые в конструкции оголовка опор имеют заземлённые неизолированные метамлические траверсы, оборудованные преимушественно штыревыми изоляторами и неизолированными проводами, а также укомплектованные мругим оборудованием с близко расположенными контактами напряжения и заземлёнными устройствами, которые эксплуатируются без диэлектрических птицезашитных устройств (Салтыков, 2014).

С целью выявления погибших орлов опоры ^ЭП среднего напряжения 6-10 кВ и пространство под ними осматривались в основном только попутно, по ходу слеАОвания экспедиционного автомобиля, мибо прово иились выборочные осмотры отАельных отрезков АЭП. Эти Аействия проводимись во время поиска гнёз на ранее необследованных территориях в начале сезона размножения и по его окончанию, а также во время мониторинга гнездования и посешения гнёз с целью кольцевания птенцов.

Мечение птенцов крупных хишных птиц цветными кольцами бы^о начато в Татарстане в 2012 г. и продолжено в последуюшие годы. Кольцевание проводилось в периол возраста птенцов преимушественно от $30 \Delta$ о 60 нней. $\Delta$ я орланов-белохвостов этот перио прихо ился в основном на конец мая и первую половину июня. $\Delta$ ия орлов-могильников - с 6-10 июля по нача^о августа. А^я большого подорлика - на вторую половину июля. Птенцы метились непосредственно на гнёздах.

Птенцы орланов-белохвостов метились цветными кольцами Средневолжской цветовой схемы, птенцы орлов-могильников и больших подорликов - кольцами, предназначенными мля Волго-Уральского региона по программе кольцевания хишных птиц Российской сети изучения и охраны пернатых хишников (Карякин и мр., 2018а). На кольцах имеется ахрес сайта Сети (WWW. RRRCN.RU) и в разделе «Кольцевание» ${ }^{18}$ размешена фрреймом Б $\Delta$ «Кольцевание».
The tagging of nestlings of large birds of prey with colored rings has started in Tatarstan in 2012 and continued in subsequent years. Nestlings of eagles were tagged with colored rings of RRRCN (Karyakin et al., 2018a). Information was posted in the "Ringing" database ${ }^{\mathbf{1 8}}$. Two nestlings of the Imperial Eagle were also tagged with ARGOS/GPS transmitters in 2016 and 1 nestling with Aquila-33 GPS/GSM tracker in 2019, 11 nestlings of the White-Tailed Eagle and 1 nestling of the Greater Spotted Eagle were tagged with Aquila-33 GPS/GSM trackers in 2018-2020 (Karyakin et al., 2018b; Karyakin et al., 2019; author's data).

In order to communicate with the population on obtaining information on the dead birds, events on eagle study in Tatarstan were regularly covered in social networks and the media for several years.

Examination of places of bird deaths was carried out with fixing coordinates, finding out owners of power lines, type of equipment and poles on which birds had died, etc., were made on the facts of finding dead birds or their remains during field surveys, as well as during checks of citizens' reports (Matsyna, Zamazkin, 2010). Particular attention was paid to the areas of electrocution on bird dead bodies, the presence of rings and trackers.

Already known methods were used to estimate the day of the bird death (Loktev, Fedosyutkin, 1992; Shnayder et al., 2020).

\section{Results and discussion}

I. Deaths and behavior of Imperial Eagles (Aquila heliaca) on power lines in the native area

\section{Review of published data}

1.1. In 2012, random examinations of power lines in the southeastern regions of Tatarstan resulted in findings of remains of immature Imperial Eagles under $10 \mathrm{kV}$ power lines owned by Tatneft PJSC: in the vicinity of Almetyevsk on May 8, and in the Aznakaevsky District on October 26 (Bekmansurov, Karyakin, 2013). In both cases dead birds could have been from the nearest breeding territories.

Ringing of eagle nestlings with colored rings further showed that the death of fledglings in most cases occurred on power lines within breeding areas.

1.2. An immature Imperial Eagle died $2.7 \mathrm{~km}$ away from the nest - the dead bird was found on September 3, 2014, in the Novosheshminsky District on a $10 \mathrm{kV}$ electric pole owned by Troitskneft CJSC (Karyakin et al., 2015).

18 http://rrrcn.ru/ru/ringing 
На территории Татарстана 2 птенца орма-могильника были помечены ARGOS/ GPS трансмиттерами в 2016 г. в рамках Российско-Венгерского проекта по $\Delta$ руководством И.В. Карякина и М. Хорвата (Карякин и мр., 2018b) и 1 птенец - GPS/ GSM-трекером Ecotone в 2019 г. Птенцы помечены на разных гнёздах в нефртегазодобываюших районах республики: в Бавлинском, Бугульминском и Мензелинском, непосредственно перед вылетом их из гнёзА.

В Волжско-Камском государственном природном биосорерном заповеднике было проведено мечение птенцов орланов-белохвостов GPS/GSM-трекерами Aquila-33: в 2018 г. были помечены 5 птенцов (Карякин и мр., 2019), в 2019 и 2021 гг. - по 2 птенца. В 2021 г. 1 птенец орлана-белохвоста также бы^ помечен в верховьях Куйбышевского водохранимиша на территории Государственного природного заказника комплексного профриля «Чистые куга» (проект по изучению миграций и территориальных связей орлана-белохвоста польержан благотворительным фрондом «Красивые дети в красивом мире»).

В 2019 г. GPS/GSM-трекерами Aquila-33 были помечены 2 птенца орланов-белохвостов в национальном парке «Нижняя Кама» в Елабужском районе и 1 птенец большого подорлика на сопредельной с национальным парком территории в Нижнекамском районе в рамках проектов Российской сети изучения и охраны пернатых хишников на средства гранта благотворительного фрон аа «Татнефрть» и на спонсорские средства Кордиана Бартошука.

Аля связи с населением по получению инорормации по погибшим птицам регулярно в течение ряда лет в социальных сетях и СМИ освешались события по изучению орлов в Татарстане.

По фрактам находок трупов птиц или их останков во время полевых исследований, а также при проверке сообшений гражАан проводился осмотр мест гибели птиц с фриксированием координат, выяснением владельцев АЭП, типа оборудования и опор, на которых погибли птицы и т.п. (Мацына, Замазкин, 2010). Особо обрашалось внимание на участки поражения электротоком на трупах птиц, наличие колец и трекеров.

Оценка Аавности гибели птиц проводилась по уже известным методикам (Локтев, Федосюткин, 1992; Шнайдер и мр., 2020).
1.3. The mummified body of the Imperial Eagle, also with colored rings on its legs, was found on the head of the anchor pole of the $10 \mathrm{kV}$ power line that feeds the oil pumping unit (Bavlyneft NGDU) and removed from the pole by power engineers on November 25, 2014. The bird died $260 \mathrm{~m}$ away from the nest, where it was born the same year (Karyakin et al., 2015).

1.4. In the second half of August 2015, the dead body of an immature Imperial Eagle was found on the outskirts of Almetyevsk under the pole of a $10 \mathrm{kV}$ power line dangerous to birds owned by Tatneft PJSC. According to the rings on its legs, it was established that it was also a fledgling of the current year, which died at a distance of about $11.7 \mathrm{~km}$ from its nest (Bekmasurov et al., 2016).

1.5. One out of two nestlings, tagged by ARGOS/GPS transmitters at different nests in the Bavlinsky and Bugulminsky Districts in July 2016, returned to Tatarstan after the first wintering and died from electrocution on the power line. The bird died in July 2017 and was found by a transmitter signal on April 15, 2018, in the Bugulminsky District under the angle pole of a $6 \mathrm{kV}$ power line owned by Grid Company OJSC (Karyakin et al., 2018a).

\section{Review of new data on the deaths of Imperial Eagles}

In 2020-2021, 5 new deaths of Imperial Eagles on 6-10 kV power lines were identified within southeastern Tatarstan.

2.1. In the vicinity of the village of Chupaevo, Almetyevsky District, near the Almetneft oil shop, on August 19, 2020, a 3-yearold dead eagle with the colored rings AA0388-8D and C-588 was found. It was established that the dead bird had been ringed in the nest in Sarmanovsky District of Tatarstan on July 19, 2017. The corpse was found near a transformer and an anchor pole with the energy isolating device, their contacts were not protected by special bird protection devices (fig. 1).

2.2. At the end of September 2020, locals of the village of Novaya Kashyrovka found the dead body of the Imperial Eagle fledgling with colored rings AB-0419-1E and B-419 under an intermediate pole of a $6 \mathrm{kV}$ power line, also owned by oil workers (Dzhalilneft, feeder 3107). The finding was reported to the district representative of the State Committee of the Republic of Tatarstan for Biological Resources, who took the corpse and brought it to the state veterinary laboratory for analysis for infectious diseases, forgetting or intentionally not reporting that the bird died from electrocution. The 


\section{Результаты и обсужмения}

І. Гибель и поведение орлов-могимьников (Aquila heliaca) на АЭП в нативной обмасти

В начале наших исследований уже были известны 2 случая гибели молодых орлов-моги^ьников первого года жизни на АЭП 6-10 кВ в Нижнекамском и Аениногорском районах Татарстана (Бекмансуров и мр., 2010). Это уже показыва^о, что в юго-восточных районах республики (Высокое лесостепное Заволжье) смертность орлов в электросетевой среде наибольшая за счёт высокой плотности гнезАяшихся пар этого вида и наибольшей плотности птицеопасных АЭП 6-10 кВ. Высокая п^отность птицеопасных АЭП здесь связана с Аобычей нефти.

\section{1. Обзор опубликованных манных}

1.1. В 2012 г. выборочные обследования АЭП в юго-восточных районах Татарстана привели к находкам останков молодых орлов-могильников. Так, 8 мая в окрестностях г. Альметьевска в поле под проме-

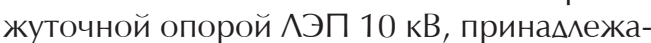
шей ПАО «Татнефрть», А.В. Салтыковым бы^и обнаружены останки молодого орма-могильника (слётка), погибшего осенью 2011 года. Нами 26 октября обнаружены перьевые останки молодого орла-могильника (слётка) в Азнакаевском районе в окрестностях $\Delta$. Курай-Елга, гАе птицеопасная АЭП проходила по возделываемому полю, поА промежуточной опорой № 27 АЭП 10 кВ ПАО «Татнефрть» (фридер 6910) (Бекмансуров, Карякин, 2013). Судя по останкам, птица погибла более месяца назах. В обоих случаях погибшие птицы могми быть с ближайших гнезАовых участков.

Кольцевание птенцов орлов цветными кольцами в Аа^ьнейшем показа^о, что гибель молодых птиц-слётков в большинстве

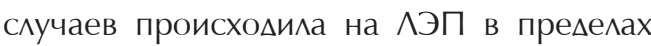
гнезАовых территорий.

1.2. Местный житель стал свидетелем гибели молодого орла-могильника, присевшего на оголовок промежуточной опоры ^ЭП 10 кВ, приналмежашей 3 АО «Троицкнеорть», в Новошешминском районе 3 сентября 2014 г. Птица получила ожоги в результате воздействия электротока. По кольцам на лапах птицы установлено, что она погибла на расстоянии 2,7 км от гнезАа, в котором родилась в этом же году (Карякин и мр., 2015).

1.3. Мумиорицированный труп орла-могильника, также имевшего цветные кольца на лапах, бы^ обнаружен на оголовке анкерной опоры АЭП 10 кВ, питаюшей не- dead eagle was a fledgling that had recently left a nest located $2 \mathrm{~km}$ away from the place of death. The bird was ringed in this nest on July 8, 2020, and was the second female in a brood of three nestlings. Thus, the bird died within its breeding area in the second month after leaving the nest (fig. 2).

2.3. On the same day, September 29, 2020, a report of a local resident about a dead bird on an oil workers' power line in the Aznakaevsky District of the Republic of Tatarstan to the north of the Buraly village was checked. The body of an immature Imperial Eagle, also a fledgling, having recently left the nest, was found on the head of one of the anchor poles. The position of the corpse showed that the bird had short-circuited the contact wire and metal cross-arm with its body, which caused the death as a result of short circuit. According to the report, the bird had been hanging on the pole for more than a day (fig. 3). The fledgling died at a distance of about $600 \mathrm{~m}$ from the nest in which it was born.

2.4. During the survey of a new Imperial Eagle breeding territory in the Sarmanovsky District of the Republic of Tatarstan, a 6-10 kV power line dangerous for birds, which brings electricity to the oil pumping units, was examined near the breeding territory on September 19, 2020. A significant part of it is also made on pin-type insulation, part of the line is made on suspended insulators. The remains of the Imperial Eagle fledgling, which died in the second half of August, were found almost $300 \mathrm{~m}$ away from the nest under the angle pole. The angle pole was made of metal pipes and had pin-type insulation without bird protection devices (fig. 4).

2.5. The report about finding the body of an eagle under an oil workers' power line in the vicinity of the village of Novaya Kashirivka, Almetyevsky District, was received again on September 7, 2021. And once again the dead bird was a fledgling from the same nest from which the immature bird died in 2020 . The newly dead eagle also had colored rings on its legs (AA-0481-8E and H-481). It was tagged in this nest on July 10, 2021, and was morphometrically measured to be a male. The distance from the nest to the death site was about $400 \mathrm{~m}$ (fig. 5).

This nest had been under video monitoring with online broadcast via the Internet since March 2021. Therefore, the death of the immature bird caused a massive public outcry, which led to a detailed accident investigation and imposition of fines and an order to equip the power lines with birdprotection devices. 
фртекачалку (НГАУ «Бавлынеорть») и снят с опоры энергетиками «Бавлынефрть» 25 ноября 2014 г. Птица погибла на расстоянии 260 м от гнезда, гле родилась в этом же году (Карякин и мр., 2015). Судя по всему, труп висел на опоре уже более 1 месяца, так как утрати^ все внутренние мягкие ткани и всё это время не вызывал отк^ючение минии.

1.4. Во второй половине августа 2015 г. (точная Аата неизвестна) начальник районного отьела по Альметьевскому муниципальному району Управления по охране и использованию объектов животного мира Республики Татарстан А.Г. Муртазин обнаружил труп молодого орла-могильника на окраине г. А^ьметьевска. Труп лежал под

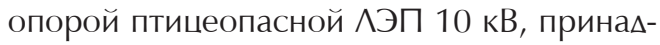
лежашей ПАО «Татнефрть». Аапы птицы обгорели. Труп птицы был в стации разможения внутренних мягких тканей, обгоревшие кожные покровы лап показывали, что птица погибла от поражения электротоком. По кольцам на лапах установлено, что это также бы^ слёток текушего года, погибший на расстоянии около 11,7 км от своего гнезда (Бекмансуров и мр., 2016).

1.5. Опрехелённый показатель по гибели орлов на АЭП в нативной области Аало мечение птенцов GPS трансмиттерами. Так, из Авух птенцов, помеченных ARGOS/GPS трансмиттерами на разных гнёздах в Бавминском и Бугульминском районах в июле 2016 г., один после первой зимовки вернулся на территорию Татарстана и погиб на АЭП в результате поражения электротоком. Сигнал от передатчика пропал в июле 2017 г. Но неожиланно «оживший» переАатчик весной 2018 г. показал местоположение трупа птицы. Он бы^ обнаружен 15 апреля 2018 г. в Бугульминском районе по угловой опорой АЭП 6 кВ, принахлежашей ОАО «Сетевая компания» (фрилер 20-09 ПС Микулино, Бугульминский РЭС). От трупа остались скелет и перья, а также цветные кольца и трансмиттер (Карякин и sp., 2018a).

\section{2. Обзор новых Аанных по гибели ор- АОв-могимьников}

В 2020-21 гг. в Татарстане были выявлены 5 новых случаев гибели орлов-могильников на АЭП 6-10 кВ. Все фракты гибели также в пределах Восточного Закамья (Высокое лесостепное Заволжье). В большинстве случаев инорормация о гибели птиц была получена в результате взаимодействия с гражданским населением, заинтересованным в сохранении биоразнообразия.
Analysis of the presented data shows that immature birds under 3 years of life died on 6-10 kV power lines dangerous to birds $(n=11)$. Ten out of eleven dead birds died on oil workers' power lines, 1 died on the power lines of the Grid Company.

The percentage of fledglings that died near breeding territories after leaving the nests was $81.8 \%(n=9)$; one bird died in the second year of life and one bird died in the third year of life. The death of fledglings was identified in 8 breeding areas (one of them twice), which is $3.9 \%$ of all known breeding areas of the Imperial Eagle by the end of $2021 \quad(n=205)$ and about $7.2 \%$ of 111 breeding territories in 16 administrative regions of the southeast of Tatarstan, where oil production is carried out. Among them 4 deaths of fledglings were identified in Almetyevsky District in 3 breeding areas, making 20\% of 15 known in the district. In Aznakaevsky District, where 11 breeding areas are known, 2 deaths occurred near 2 of them; 1 case each in Sarmanovsky and Novosheshminsky Districts, where 10 and 4 breeding areas are known respectively.

Two eagles out of 6 fledglings, for which a time interval of death was set, died in the second half of August, and 2 eagles also died in the first and second halves of September.

Distances from the precisely known nests to places of fledging death ranged from 0.26 to $11.7 \mathrm{~km}, 2.56 \mathrm{~km}$ on average $(n=7)$. In $57.1 \%$ birds died at distances less than $1 \mathrm{~km}$ (from 260 to $600 \mathrm{~m}$ ), while $28.6 \%$ died at distances from 2 to $3 \mathrm{~km}$. Six eagles died on intermediate poles, while five eagles died on angle and anchor poles.

Taking into account that practically all finds were accidental, the real mortality rate of Imperial Eagles on power lines may be much higher. The deaths of fledglings from the same nest in 2020 and 2021 in the vicinity of the village of Novaya Kashirovka in Almetyevsky District shows that the death of birds in the breeding areas may be regular. Moreover, there are power lines dangerous to birds near each nest of eagles.

At the same time, regular returns of rings and reports of observations of alive eagles ringed in Tatarstan on migration routes and wintering grounds show that a large part of immatures leaving nests manage to survive in the dense network of dangerous to birds environment in the native area.

One bird out of three fledglings of Imperial Eagles, tagged with trackers in 2019 in the Menzelinskiy District, is currently alive. However, all birds survived at the beginning of the first days of post-nesting movements and along the route of the first migration. Electro- 
2.1. От местного жителя поступило сообшение о находке трупа 3-х метнего орла в окрестностях с. Чупаево А^ьметьевского района вблизи с неортяным цехом ЦН $\Delta Г 2$ НГАУ «А^ьметьнефрть» 19.08.2020 г. У орла на лапах имелись цветные кольца волгоуральской цветовой схемы. По их номерам (АА-0388-8D и С-588) установлено, что погибшая птица была окольцована будучи птенцом в гнезде в Сармановском районе Татарстана (Аата кольцевания 19.07.2017 г.). С момента гибели птицы,

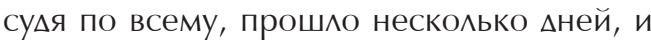
труп уже был в мумифрицированном состоянии. Анализ присланных оротограорий показа^, что на кожных покровах лап имелись обугленные участки, как это происходит при поражении электротоком на ^ЭП. Труп най еен вблизи трансорорматора и анкерной опоры с разьединительным устройством, их контакты не зашишены специальными птицезашитными устройствами. Ближайшие опоры промежуточного типа выполнены на подвесной изоля-

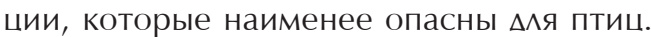
Судя по всему, орёл погиб от электротока, присев на анкерную опору с разъединительным устройством, и в последуюшем труп был несколько смешён в сторону от места гибели (рис. 1). Мы получили сообшение спустя несколько Аней. К тому времени следов трупа на месте гибели уже не было.

2.2. В конце сентября 2020 г. местными жителями с. Новая Кашировка Альметьевского р-на обнаружен труп слётка орламогильника с цветными кольцами на лапах (АВ-0419-1E и В-419) пол промежуточной

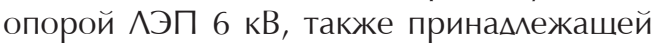
нефртяникам (НГАУ «Ажалильнефрть», фример 31-07). О находке было сообшено районному представителю Государственного комитета Республики Татарстан по биомогическим ресурсам, который изъял труп и достави^ его в государственную ветери-

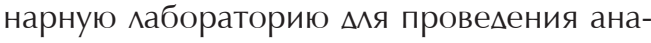
миза на предмет выявления инорекционных заболеваний. В результате инорекционных патологий у птицы не выявлено, но ветеринарами не была указана причина смерти птицы, хотя наверняка были наружные ожоги и внутренние повреждения, вызванные воздействием электротока.

Сообшение о оракте гибели этого орла было получено 29.09.2020 г. Осмотр места гибели показа^, что ^ЭП, подводяшая электроснабжение к нефртекачалкам, проходит по пастбишу на северной окраине села Новая Кашировка. Опоры АЭП cution on a power line dangerous for birds in the native area occurred only in one case, after the return from the first wintering of one of the two eagles tagged in 2016.

At the same time, during all the years of our studies we did not reveal facts of death of adult birds on 6-10 kV power lines. Every year we met up to two dozen adult birds on electric poles in the breeding areas. In all cases some selectivity in the choice of a perching site was observed. Normally, we met adult birds on poles of high-voltage power lines, starting from $35 \mathrm{kV}$ and higher, in the construction of which the contact wire is significantly distant from the place that the bird chooses for perching. 6-10 kV power lines with wooden poles without insulator hooks grounding in Tatarstan remained in small numbers. We registered only one meeting of an adult eagle on a wooden pole in Alkeevsky District. However, adult birds in Tatarstan distinguish and often use as perching sites 6-10 kV power lines with suspended structures that appeared in the beginning of the XXI century, mainly from oil companies. Eagles mostly use the upper bar of the metal crossbeam of intermediate poles (fig. 6).

We made an observation of an adult Imperial Eagle on July 20, 2020, that was hunting for voles near its breeding territory in the Sarmanovsky District of Tatarstan. The land was being tilled, and the eagle was watching the tractor movement, sitting on a metal traverse with suspended insulators of the reinforced concrete pole head of the $6 \mathrm{kV}$ power line belonging to oil workers. There were 4 other power lines of the same voltage close to each other, but all of them had pin-type insulators in the head structure. The eagle chose the safest one out of 5 power lines that are parallel (fig. 7).

On the one hand, the traverse structure with suspended insulators looks convenient for perching and that is why it is probably used by eagles. On the other hand, there may be a purposeful avoidance of pin-insulated power lines dangerous for birds. Nevertheless, this example clearly shows the selective behavior of eagles in choosing safer perching site. This adaptive behavior in the electric grid environment is either formed by the selection of habitual and convenient perch qualities or "formed by two main factors: (1) the frequent deaths of birds not avoiding power lines dangerous for birds, and (2) the formation of a stereotypic avoidance of such lines by birds, supported by selection" (Shnayder et al., 2020). We twice observed adult eagles picking up dead rooks under the poles of 6-10 kV power lines. Moreover, eagles often witness the death of other congeners, including their nestlings. 
Рис. 1. Птицеопасный участок АЭП 6-10 кВ с неизолированными контактами разьединительного устройства и трансорорматора, фрихер 20-05 близ с. Чупаево в А^ьметьевском районе и труп орла-могильника (Aquila heliaca) с кольцами AA-0388-8D и

C-588 на лапах (внизу). Фото А. Игнатова. Этот же орёл в гнезде в Аень кольщевания 19.07.2017 г. (вверху). Фото Р. Бекмансурова.

Fig. 1. A section of the 6-10 kV power line dangerous for birds with uninsulated contacts of the energy isolating device and transformer, feeder 20-05 near the village of Chupaevo in Almetyevsky District and a corpse of the Imperial Eagle (Aquila heliaca) with rings AA-0388-8D and C-588 on its legs (bottom). Photo by A. Ignatov. The same eagle in the nest on the day of ringing on July 19, 2017 (upper). Photos by R. Bekmansurov.

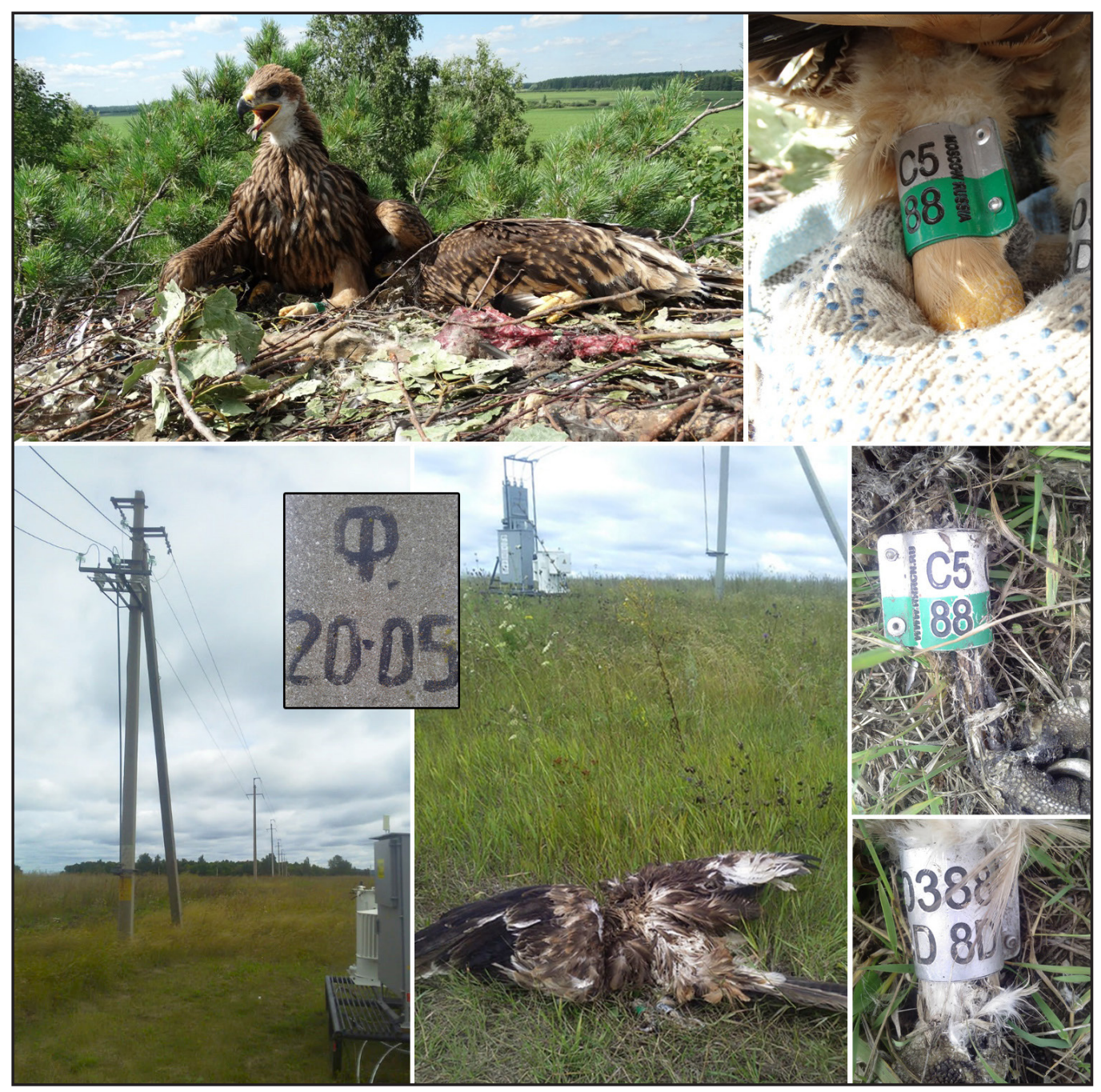

железобетонные с креплением неизолированных проводов на штыревых изоляторах с метамиической неизолированной заземлённой траверсой. Такая конструкшия является опасной Аля птиц. Контакты на разъединительных устройствах и трансорорматорах $а$ анного фридера также не изолированы и опасны мля птиц. Расположение АЭП на пастбише, которое входит в охотничий участок гнездяшейся поблизости пары орлов-могильников, созмаёт опасную среду м^я обитания редкого «краснокнижного» виАа. Погибший орёлмогильник являлся слётком, неАавно покинувшим гнезАо, которое расположено в 2 км от места гибели. Птица была окольцована в этом гнезде будучи птенцом 8 июля 2020 г. и являлась самкой - второй птенец в выводке из трёх птенцов. Таким образом, птица погибла в пределах своей гнездовой территории на второй месяц после вылета из гнезАа, что обычно происходит в первую половину августа (рис. 2).

2.3. В этот же $е$ ень 29 сентября 2020 г. было проверено сообшение местного жителя о трупе птицы на АЭП неотяников в
The increase in the number of pairs nesting on the poles of high-voltage power lines can also be attributed to adaptation to the electric grid environment and the formation of selective behavior.

During 2011-2015, 5 breeding territories with nests on electric poles were found in the southeast of Tatarstan (Bekmansurov, 2015). In subsequent years, 3 more breeding territories were identified in Aznakaevsky (2) and Sarmanovsky (1) Districts. Thus, the adaptation of Imperial Eagles to the electric grid environment continues (fig. 8).

\section{Death of White-Tailed Eagles (Haliaee-} tus albicilla) on power lines in the native area

During monitoring of the White-Tailed Eagle breeding, we recorded electrocution of an immature White-Tailed Eagle on the intermediate pole along the highway in the field in the Spassky District of Tatarstan on July 17, 2012. The bird died on the day of its find (Bekmasurov et al., 2012a).

According to the results of eagles ringing with colored rings and tagging with GPS/GSM-trackers (Karyakin et al., 2019; the author's data), 
Рис. 2. Птицеопасная АЭП 6 кВ нефртяников на окраине с. Нов. Кашировка Альметьевского р-на в месте гибели слётка орламогимьника в сентябре 2020 г. (внизу слева). Труп орла в Аень его обнаружения поА АЭП и кольца (АВ-0419-1E и B-419), снятые с него (внизу справа). Это был один из трёх птенцов, помеченных в гнезде 08.07.2020 г. (вверху). Фото Р. Бекмансурова.

Fig. 2. Power line $6 \mathrm{kV}$ dangerous for birds on the outskirts of the village of Novaya Kashirovka in Almetyevsky District at the site of the death of an Imperial Eagle fledgling in September 2020 (bottom at the left). The eagle's corpse on the day it was found under a power line and rings (AB-0419-1E and B-419) removed from the eagle's corpse (bottom at the right). This was one of three nestlings tagged in the nest on July 8, 2020 (upper). Photos by R. Bekmansurov.
Азнакаевском районе РТ к северу от села Буралы. Осмотрены 2 парамлельно расположенные птицеопасные ^ЭП среднего напряжения в поле вАоль Аороги нефртяников севернее села Буралы. Опоры АЭП железобетонные с креплением неизолированных проводов на штыревых изоляторах с метамлической неизолированной заземлённой траверсой. На оголовке одной из анкерных опор обнаружен труп молодого орла-могильника, также слётка, недавно покинувшего гнездо. Положение трупа показывало, что птица перемкнула своим телом контактный провод и метамическую траверсу, что и яви^ось причиной смерти в результате короткого замыкания. Судя по всему, это не повлияло на отк^ючение минии и проверку АЭП энергетиками нефртяной организации. Птица, согласно сообшению, висела на опоре уже не один мень (рис. 3). Ближайшее от места гибели известное нам гнезАо орла-могильника располагалось на расстоянии около 4 км, но оно в 2020 г. не занималось орлами. their deaths on power lines in the native area were not registered. But eagles inhabit Tatarstan year-round, and their winter nomadic migrations are far from water, including in oil and gas producing areas where there are always power lines dangerous for birds. The small quantity of mortality data is most likely due to the lack of continuous monitoring of power lines dangerous for birds, including near breeding territories in the first months after the nestlings leave the nest. Thus, on August 16, 2019, during the examination of the known breeding territory of the White-Tailed Eagle in the Rybnoslobodsky District of Tatarstan at a distance of about $50 \mathrm{~m}$ from the nesting tree under the intermediate pole of the $6 \mathrm{kV}$ power line, the remains of a WhiteTailed Eagle fledgling were found. This power line on reinforced concrete poles with noninsulated wires mounted on pin-type insulators runs along a cleared strip through a large forest area along the bank slope of the Kama River. The width of the cleared strip is about $10 \mathrm{~m}$ (fig. 9). The trees in this strip are much

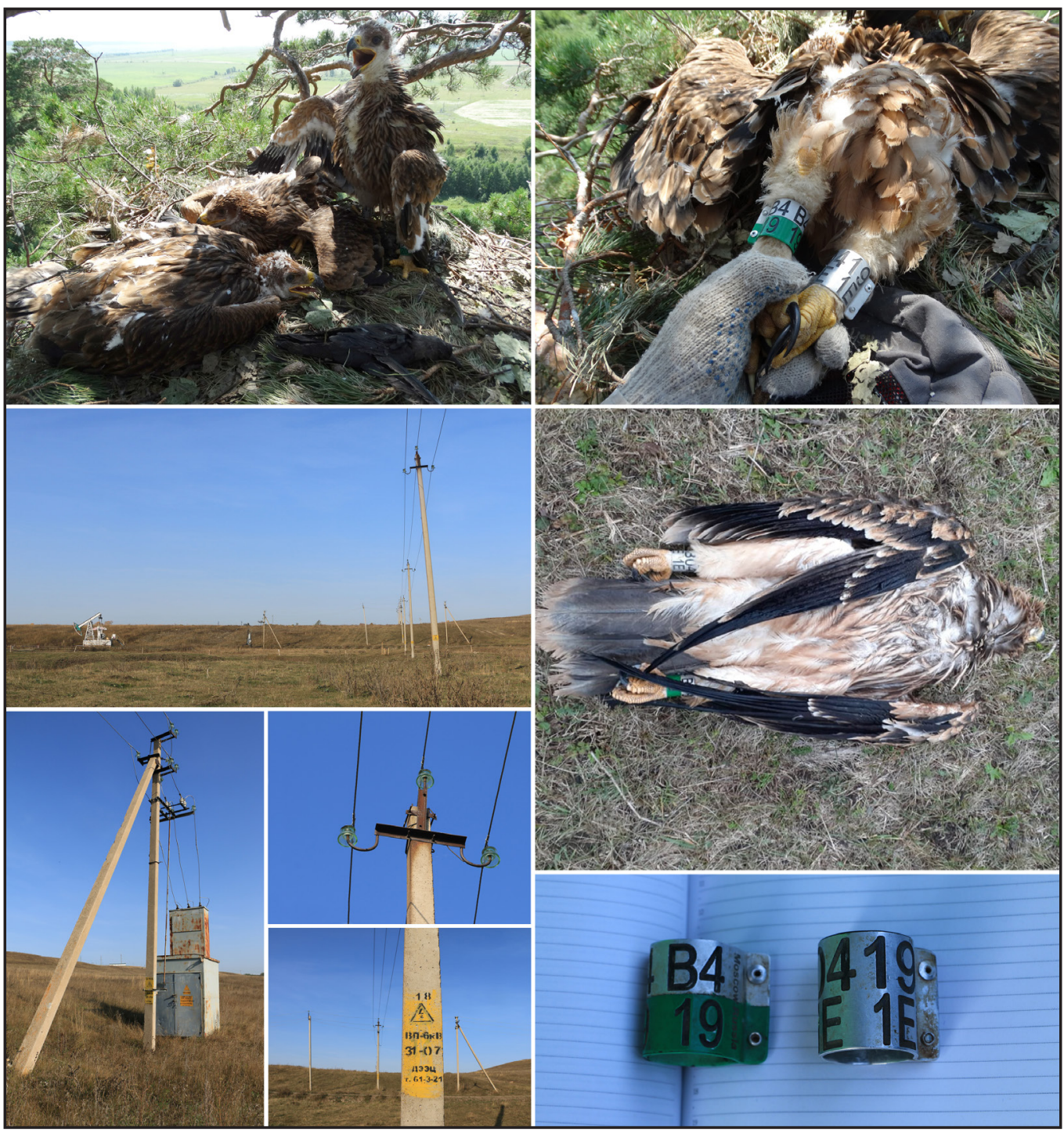




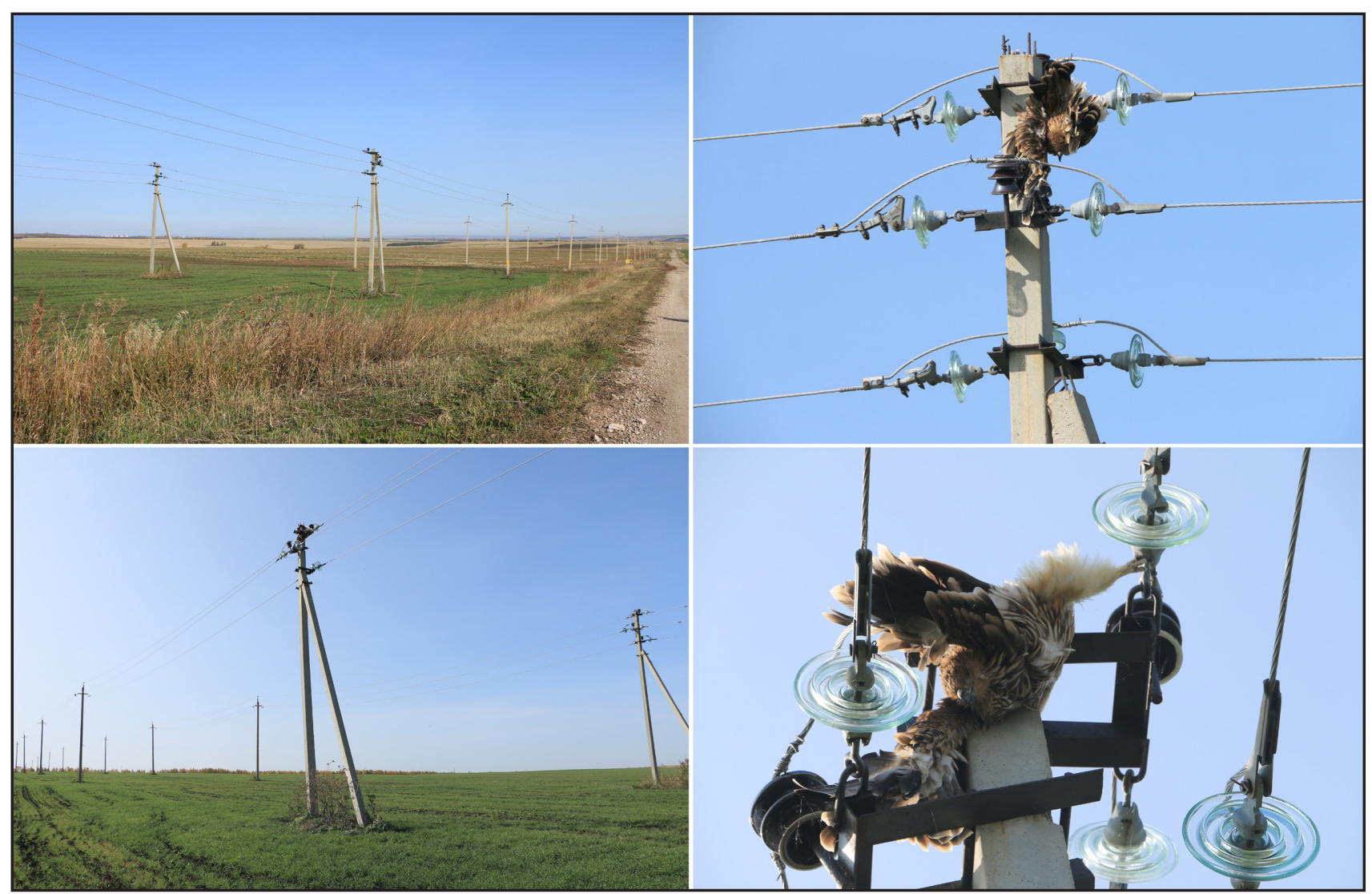

Рис. 3. $\Delta$ ве паралельные птицеопасные $\bigwedge Э П$ 6-10 кВ нефртяников в окрестностях С. Буралы Азнакаевского района (слева) и труп молоАого орла-могильника (слётка) на оголовке анкерной опоры (справа). Фото Р. Бекмансурова.

Fig. 3. Two parallel oil workers' 6-10 kV power lines dangerous for birds in the vicinity of the village of Buraly, Aznakaevsky District (at the left) and the corpse of an immature Imperial Eagle (fledgling) on the head of the anchor pole (at the right). Photos by R. Bekmansurov.
Поэтому в Аальнейшем были предприняты Аополнительные поиски гнезАа, и оно было обнаружено совсем близко от места гибе^и, на сельском кладбише. Таким образом, слёток погиб на расстоянии около 600 м от гнезАа, в котором родился.

2.4. Только что выявленный гнездовой участок орла-могильника с гнезАом в полезашитной ^есополосе, устроенном на берёзе, был осмотрен в Сармановском районе РТ 19 сентября 2020 г. ГнезАо неАавно было покинуто птицами и имело все признаки прошедшего размножения, в том числе множество пишевых остатков пол гнезАом на земле. Вблизи гнезАового участка также проходит птицеопасная ^ЭП 6-10 кВ, которая подводит эмектричество к нефртекачалкам (фрилер 81-04). Значительная её часть также выполнена на штыревой изоляции, часть минии выполнена на подвесных изоляторах. На расстоянии почти 300 м от гнезАа под угловой опорой обнаружены останки слётка орламогильника в виде полного набора перьев и костных останков. Слёток погиб, вероятно, во второй половине августа. Угловая опора изготовлена из метамиических труб и имеет штыревую изоляцию без птицезашитных устройств (рис. 4).

2.5. Сообшение о находке трупа орла

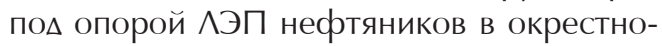
стях с. Новая Кашировка Альметьевского higher than the reinforced concrete poles, the standard height of which is $10 \mathrm{~m}$. The death of the bird affected the installation of plastic bird protection devices on electric poles nearest to the nest.

The case described above showed that immature eagles also die in the first days and months after leaving their nests. Their death is possible not only on power lines located in open landscapes, but also in the depths of the forestland on narrow forest cleared strips. This was recorded the next year in the Udmurtia National Park "Nechkinsky", where on July 12, 2020, in a Intra-forest clear-cut strip 2 dead immature eagles were found immediately under the nearest intermediate concrete poles of a 6-10 kV power line with pin-type insulation (fig. 10).

Despite the small sample of data on the death of White-Tailed Eagles, we can still conclude that immature birds of this species die first, as well as in Imperial Eagles. Nevertheless, the death rate of White-Tailed Eagles from electrocution on $6-10 \mathrm{kV}$ power lines is lower than that of Imperial Eagles. This is also confirmed by the results of GPS/GSM telemetry studies of 12 eagle nestlings tagged with trackers. Their deaths on power lines have not yet been recorded. This could be explained by the fact that in all cases of tagging and ringing breeding territories were far away from power lines dangerous to birds. We did not 
Рис. 4. ГнезАовой участок орлов-могильников в окрестностях с. Рангазар Сармановского района в иесополосе с гнезАом на берёзе (вверху) и птицеопасная АЭП нефртяников (фрихер 81-04) вблизи гнезда с птицеопасной угловой метамической опорой (в центре), под которой найдены останки слётка орла, и его перьевые останки под этой опорой (внизу).

Фото Р. Бекмансурова.

Fig. 4. Breeding territory of the Imperial Eagle near the village of Rangazar, Sarmanovsky District in the forest belt with a nest on a birch tree (upper) and oil workers' power line dangerous for birds (feeder 81-04) with angle metal pole (at the center), under which the remains of an eagle fledgling were found; the feather remains of an eagle under this pole (bottom). Photos by R. Bekmansurov.

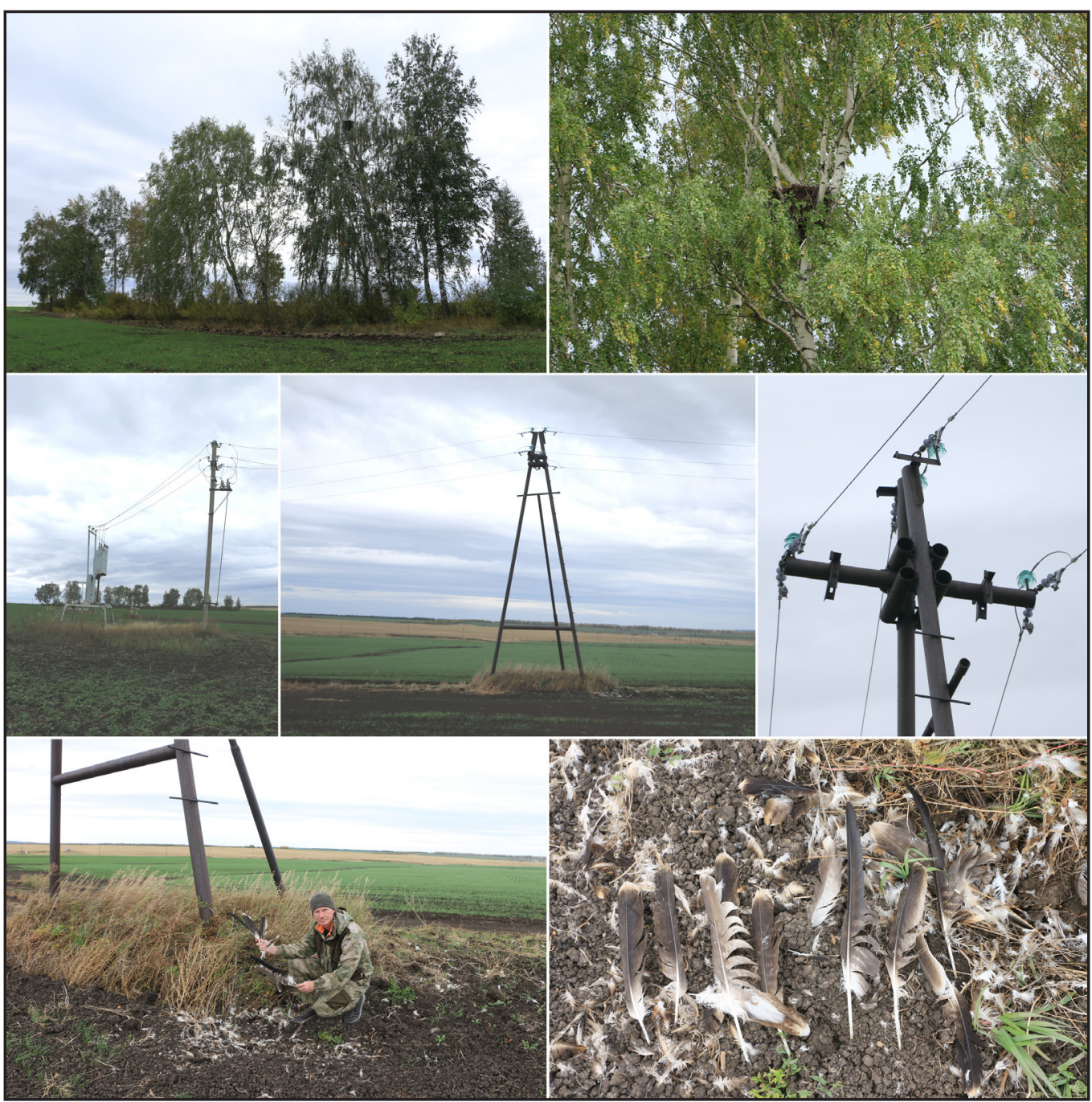

района вновь поступило 07.09.2021 г. И в очередной раз погибшей птицей стал слёток с того же самого гнезАа, с которого погибла молодая птица в 2020 г. Погибший орёл также имел цветные кольца на лапах (AА-0481-8Е и Н-481), он был помечен в этом гнезде 10 июля 2021 г. и по моророметрическим промерам являлся самцом. Расстояние от гнезда до места гибели составило около 400 м (рис. 5).

В Аанном гнезде с марта 2021 г. велось видеонаблюдение с трансляцией в онлайнрежиме посредством Интернета. И потому гибель молодой птицы вызвала широкий обшественный резонанс, приведший к полробному расследованию происшествия.

На основании полученной инорормации на место происшествия 07.09.2021 г. были направлены специалисты ООО «ТатнефртьЭнергосбыт», которые обнаружили труп орла в зоне прохожления ВА - 6 кВ фрилера 84-17 межАу промежуточными опорами № 5 и № 6 отпайки к КТП - 6/0,4 кВ нефртяных скважин 5109, 23196. На момент обнаружения труп уже начал разлагаться. С целью сохранения его целостности и вы- observe any electrocution on power lines in further post-nesting movements either.

Apparently, the network of power lines dangerous for birds in Tatarstan and neighboring regions can affect the death of other red book eagles, not nesting in Tatarstan, rare visitations of which are possible as well. Thus, on June 5, 2021, a dead Steppe Eagle (Aquila nipalensis) was found under the intermediate pole of $10 \mathrm{kV}$ power lines dangerous for birds in the adjacent territory of the Udmurtian Republic, Karakulinsky District (M.N. Zagumenov, personal communication). The owner of the power lines was not identified by the watcher, but it could be the lines of Rossneft (fig. 11).

The visitation of the Steppe Eagle farther north of its breeding range is an interesting and rare occurrence, but, unfortunately, it ended tragically for the bird. The Steppe Eagle in the steppe regions is recorded as the most susceptible to electrocution on 6-10 kV power lines among other eagle species (Karyakin, Novikova, 2006; Medzhidov et al., 2011; Karyakin, 2012; Matsyna et al., 2012; Levin, Kurkin, 2013; Pestov et al., 2015). 
яснения причин гибели он был временно изъят из природной среды и Аоставлен на

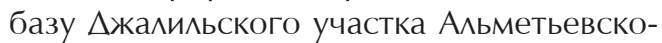
го ЭЭЦ ООО «Татнефрть-Энергосбыт» (составлен Акт изъятия объекта животного мира из природной среды). Специалисты Ажалильского участка Альметьевского ЭЭЦ ООО «Татнеорть-Энергосбыт» установили отсутствие отключения Аанного фрилера ^ЭП, которое могло быть вызвано коротким замыканием в результате воздействия птицы, и потому выразили сомнение о причине гибели птицы в результате воздействия электротока. Осмотр трупа птицы был провелён 09.09.2021 г. в посёлке городского

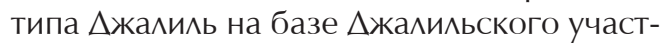

\section{Problems of 6-10 kV power line modernization}

In 2011, when planning extensive work to modernize existing power lines and prevent the construction of new power lines dangerous for birds in Tatarstan, we hoped that for 10 years we would be able to achieve solid performance in protecting birds from electrocution, at least in the breeding grounds of eagles. However, the rates of power line modernization turned out to be extremely low. Thus, Grid Company JSC, the main owner of power lines dangerous for birds in Tatarstan, will not be able to ensure the safety of birds in the next 20 years at the current rate. Often plastic covers and caps are put on the few poles

Рис. 5. Птенец орламогильника, помеченный кольцами АА-04818 и и $\mathrm{H}-481$, в гнезде в Аень кольцевания 10 июля 2021 г. (вверху), и его труп пох промежуточной опорой

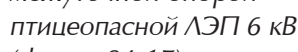
(фричер 84-17), ожоги и поврежления от электротока на пальцах орла показаны стрелками (в центре); вид на АЭП 6 кВ (фричер 84-17) в месте гибели орла (внизу).

Фото Р. Бекмансурова.

Fig. 5. Nestling of the Imperial Eagle, ringed by AA-0481-8E and H-481 rings, in the nest on the day of ringing on July 10, 2021 (upper), and its corpse under the intermediate pole of the $6 \mathrm{kV}$ power line dangerous for birds (feeder 84-17), burns and injuries from electrocution on the fingers of the eagle are presented by arrows (at the center); a view of the $6 \mathrm{kV}$ power line (feeder 84-17) at the place of the eagle's death (bottom). Photos by R. Bekmansurov.

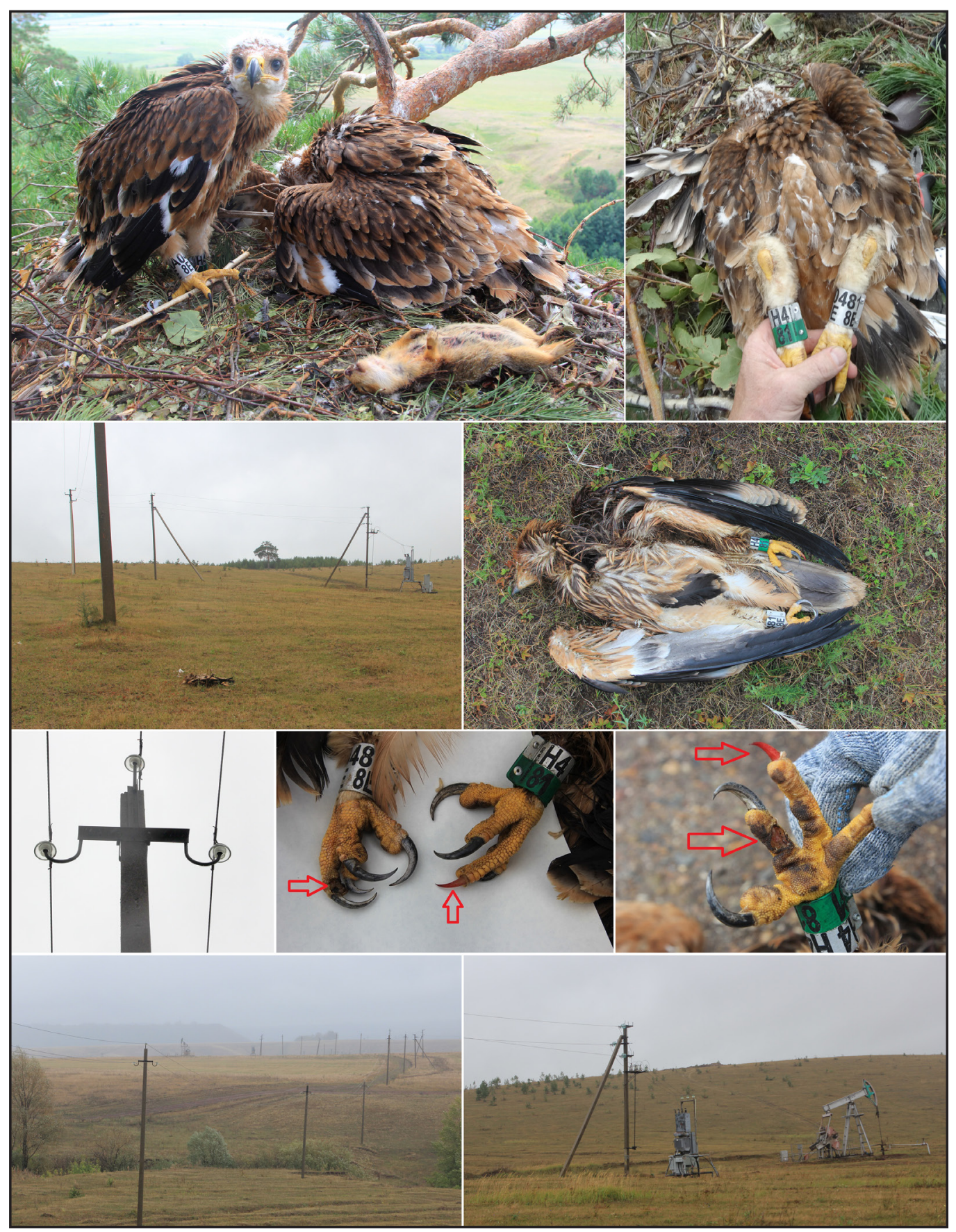


ка А^ьметьевского ЭЭЦ ООО «ТатнефртьЭнергосбыт». Труп хранился в закрытом метамическом контейнере. Целостность скелета удовлетворительная, конечности и голова не отлелены. Перьевой покров в основном в целостности, кроме отлельных участков в местах вероятного поврежления наружных тканей, которые на момент осмотра уже были подвержены значительному гниению, внутренние ткани и органы сильно изъедены мичинками насекомых, в массе размножившихся в теле трупа. Кожные покровы лап трупа птицы без признаков разможения. На них хорошо винны ожоговые поврежления в виде ран овально-округлой формы с обугленными краями. На правой лапе - с нижней стороны на среднем пальце,

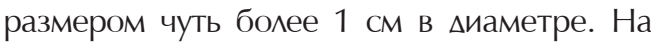
левой мапе - на внутреннем пальце, также более 1 см в диаметре. На среднем пальце левой лапы отсутствует роговой коготь, Аистальная фраланга оголена $\Delta$ костной ткани. Таким образом, наличие следов воздействия электротока, вызвавшего гибель птицы, было установлено (составлен Акт осмотра). После осмотра труп птицы был возврашён на место обнаружения с целью соблюдения правовых норм, касаюшихся видов животных (в том числе их трупов и частей тела), вкАючённых в Красную книгу Российской Фелерации, к каковым относится орёл-могильник. О возврате птицы был составлен акт. В последуюшем труп был отнесён в сторону от АЭП, чтобы не привлекать паАальшиков и не вызвать новой гибели Аругих

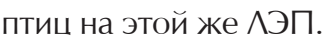

Место гибели птицы было определено по сохранившемуся кровяному пятну и оставшимся отлельным перьям на траве, а

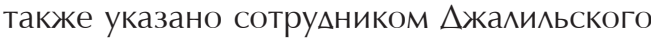
участка А^ьметьевского ЭЭЦ ООО «Татнеорть-Энергосбыт», который выезжал на поиски трупа. Место обнаружения трупа находилось в 5 м от железобетонной опоры промежуточного типа. На оголовке опоры траверса выполнена из метаммического уголка с крюками штыревого типа $\Delta$ я крепления изоляторов. Провода не имеют изоляции. Специальные птицезашитные устройства и антиприсадные устройства на оголовке опоры в местах крепления проводов у изоляторов отсутствуют. Конструкция крепления проводов является опасной мля птиц. На ближайших опорах манной ^ЭП, как и на всём её протяжении, на выходных контактах близкорасположенного трансорорматора и контактах разъединительного устройства птицезашитные устройства также отсутствуют. of the whole feeder, consisting of dozens of poles. This cannot provide complete protection of birds. During inspections of installation of bird protection devices (BPD), violations in installation, improper selection of BPDs for a particular piece of equipment, poor workmanship (fig. 12) were revealed. Poor-quality works lead to the rapid destruction of BPDs and reduction of their service life.

There are cases of construction of new power lines dangerous for birds, which is an indication that the design organizations still "release" anti-ecological projects that do not take into account the biodiversity conservation (fig. 13).

The use of self-supporting insulated wires (SIW-3) in Tatarstan raises questions of bird protection, namely the presence of numerous points of potential output, in particular in places of location of non-insulated current-carrying elements of lightning protection, piercing clamps, contacts on transformer bushings, contacts of line disconnectors, etc. (fig. 14). Lightning protection elements installed on the SIW-3 without the additional use of special BPDs can also lead to birds electrocution (Saltykov, 2020; Pestov et al., 2020).

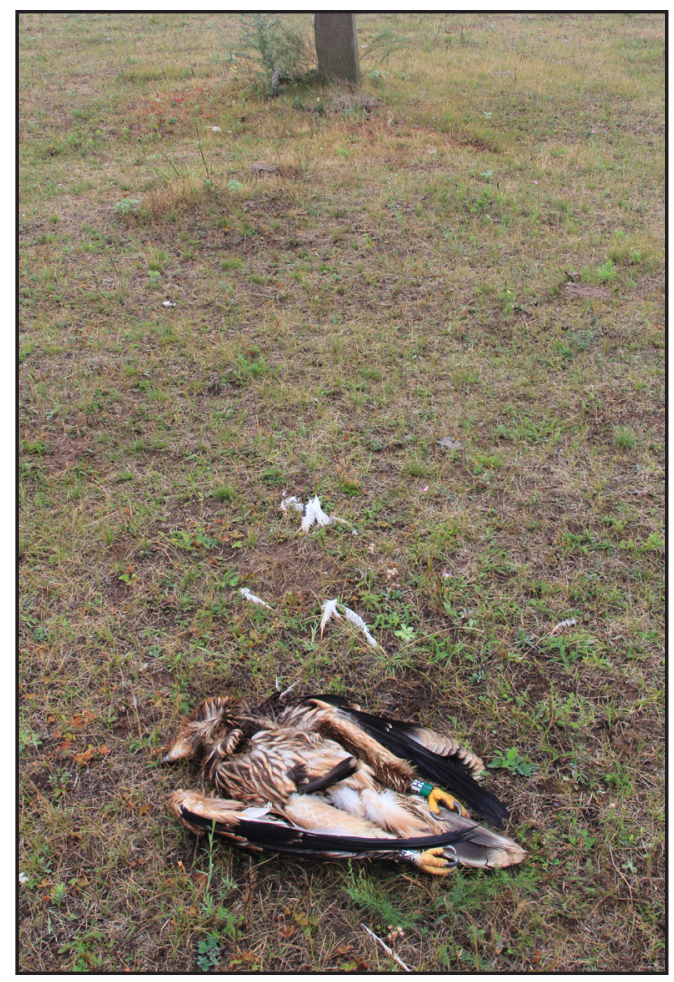

Слёток орла-могильника, помеченный кольцами AА-0481-8E и H-481, погибший на промежуточной опоре птичеопасной АЭП 6 кВ (фример 84-17). Фото Р. Бекмансурова.

Fledgling of the Imperial Eagle, ringed by AA-0481-8E and $\mathrm{H}-481$ rings, elecrocuted on the intermediate pole of the $6 \mathrm{kV}$ power line dangerous for birds (feeder 84-17). Photo by R. Bekmansurov. 


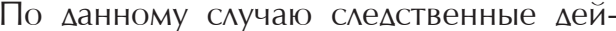
ствия были продолжены природоохранной прокуратурой, влахельцу АЭП были предьявлены штрафрные санкции и предписания оборудовать АЭП птицезашитными устройствами.

Анализ представленных Аанных показывает, что на птицеопасных ^ЭП 6-10 кВ погибли молодые птицы $\Delta$ О 3-х мет жизни $(n=11)$. Из 11 погибших птиц 10 погибли

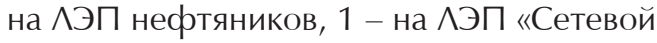
компании».

Аоля слётков, погибших вблизи гнезАовых участков после вылета из гнёзА, составила $(81,8 \%, n=9)$; одна птица погибла на второй гоА жизни и оАна - 3-х летнего возраста. Гибель слётков выявлена на 8 гнезАовых территориях (на одной из них $\Delta в а ж-$

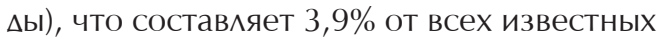
в Татарстане гнездовых территорий орламогильника к окончанию 2021 г. $(n=205)$ и около 7,2\% от 111 гнездовых территорий в 16 амминистративных районах юго-востока Татарстана, гле ведётся нефртедобыча. Из них 4 случая гибели слётков выявлены в А^ьметьевском районе на 3-х гнездовых территориях, состав^яюших 20\% от 15 известных в районе. В Азнакаевском районе, гАе известно 11 гнездовых территорий - 2 случая гибели вблизи 2-х из них; по 1 случаю в Сармановском и Новошешминском районах, в которых известно соответственно 10 и 4 гнезАовых территорий.

Из 6 слётков, м^я которых был установмен временной интервал гибели, во второй половине августа погибли 2 орла, и также по 2 орла погибли в первой и второй помовинах сентября.

$\triangle$ истанции от точно установленных гнёз $\Delta о$ места гибели слётков составими от 0,26 до 11,7 км, в среднем 2,56 км $(n=7)$. В 57,1 \% гибель произошла на расстоянии менее 1 км (от $260 \Delta$ о 600 м), В $28,6 \%$ - на $и$ итанции от 2 Ао 3 км. На промежуточных опорах погибло 6 орлов, на угловых и анкерных - 5 .

Принимая во внимание, что практически все находки были случайными, реаль-

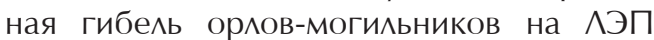
может быть значительно выше. Факт гибели слётков из одного гнезАа в 2020 и 2021 гг. в окрестностях с. Нов. Кашировки в Альметьевском районе показывает, что гибель птиц на гнездовых территориях может быть регулярной. К тому же вблизи каждого гнезда орлов имеются птицеопас-

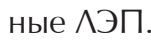

В тоже время регулярные возвраты комец и сообшения о наблюдениях живых
During the last decade, we observed how Tatneft PJSC was gradually transferring 6-10 $k \mathrm{~V}$ power lines from pin-type insulation to suspended one, which is certainly less dangerous for birds, especially medium and smallsized ones. However, these power lines have always had sections dangerous for birds in the form of traverses with pin-type and stretching insulators on anchor poles, including poles with energy isolating devices; no insulation elements were used on transformer terminals. Moreover, often due to the lowered height of the wire above the ground, oil workers used a shortened insulator string on intermediate poles, consisting of only one insulator of the tray type, which can be dangerous for large birds, such as eagles (fig. 15). Therefore, a 6-10 kV power line with suspended insulators can become completely safe only when bird protection devices are protected with dielectric material with complex wire connections on angle and anchor poles, including energy isolating devices and transformers, as well as when dielectric covers are installed near insulators on intermediate poles.

Despite the transfer of some power lines to less dangerous for birds with suspended insulators, oil companies in Tatarstan still have a huge number of 6-10 kV power lines dangerous for birds with pin-type insulators and bare wires. All cases of eagle deaths were recorded exactly on them (Bekmansurov, 2013).

\section{Conclusion}

Illegal operation and even construction of new 6-10 kV power lines dangerous for birds continues on the territory of Tatarstan. Despite the measures taken in the republic to protect birds from death in the electric grid environment, the rates and quality of these measures are such that in the near future power lines will affect the mortality of eagles in the native area. For such a species as the Imperial Eagle, power lines dangerous for birds will have a major elimination effect.

The high death rate of eagles detected in the southeastern districts of Tatarstan, where the main oil field is concentrated and, accordingly, the increased electric grid environment dangerous for birds, indicates the need to direct increased efforts to bird protection measures in these oil and gas producing areas. The main indicator of deaths revealed for fledglings within the breeding areas also points out the necessity of taking extensive bird protection measures at all types of equipment dangerous for birds within not less than $3 \mathrm{~km}$ from the centers of breeding territories in the initial stages of works with the subsequent increase in the modernization zones. 
Рис. 6. Орёл-могильник

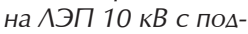
весной конструкцией крепления провода. Фото Р. Бекмансурова.

Fig. 6. Imperial Eagle on a $10 \mathrm{kV}$ power line with a suspended wire fastening structure. Photo by R. Bekmansurov.
Рис. 7. Взрослый орёл-могильник на наименее опасной промежуточной опоре АЭП неортяников С поАвесными изоляторами в окружении ешё

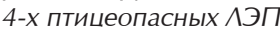
со штыревыми изоАяторами.

Фото Р. Бекмансурова

Fig. 7. An adult Imperial Eagle on the least dangerous intermediate pole of the oil workers' power line with suspended insulators, surrounded by 4 more power lines dangerous for birds with pin-type insulators. Photos by

R. Bekmansurov.

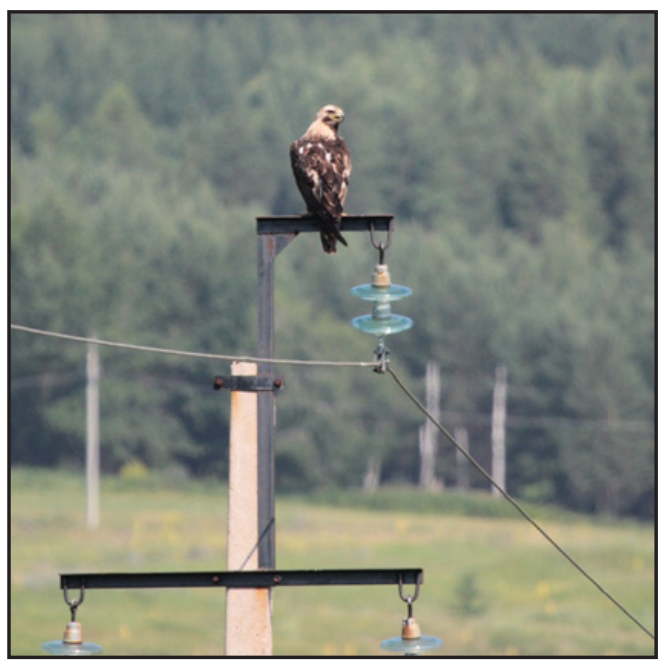

орлов, окольцованных в Татарстане, на миграционных маршрутах и местах зимовок, показывают, что значительной части мо^одых птиц, поки аюших гнёзда, у аётся уцелеть в густой сети птицеопасной среды в нативной области.

Из трёх помеченных трекерами птенцов орлов-могильников в настояшее время жива только 1 птица, помеченная в 2019 г. в Мензелинском районе. Но всем птицам удалось

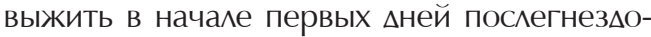
вых перемешений и по маршруту первой миграции. Гибель от электротока на птицеопасной ^ЭП в нативной области произошла только в одном случае, после возврашения

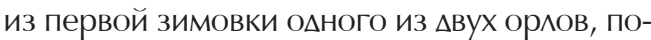
меченных в 2016 г.

Конструкция оголовков железобетонных опор ^ЭП 6-10 кВ с заземлённой метамической траверсой со штыревыми изоляторами и с неизолированным проводом практически не оставляет шансов выжить таким крупным птицам как орлы в случае выбора их в качестве присады. Но, в тоже время, за все годы наших исследований не выявлено орактов гибели взрослых птиц на АЭП 6-10 кВ.

В процессе мониторинга гнездования, в холе которого посешались гнёзда орлов преимушественно при возрасте птенцов от 30 мо 60 нней и старше, мы не выявими прерывания размножения по причине гибели территориальных взрослых птиц на АЭП. Возможно, какая-то доля гибели взрослых птиц имеет место в начале сезона размножения, так как ежегонно на части гнёз отмечено прерывание размножения на стадии клавки. Но подтвержлаю-

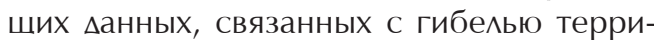
ториальных птиц на ^ЭП, мо сих пор не выявлено.

Вместе с тем, ежегодно мы встречали $\Delta о$

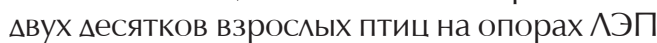
на гнездовых территориях. Во всех случаях наблюдалась некая избирательность в выборе присады. Обычно взрослые птицы были встречены на опорах высоковольтных ^ЭП, начиная от 35 кВ и выше, в конструкции которых контактный провод значительно улалён от места, которое выбирает птица мля присалы. ^ЭП 6-10 кВ с меревянными опорами без заземления крюков крепления изоляторов в Татарстане остались в небольшом количестве, и нами отмечена мишь единственная встреча взрослого орла на меревянной опоре в А^ькеевском районе. Но появившиеся в начале XXI века в Татарстане главным образом у неортяников минии 6-10 кВ с подвесными конструкциями взрослые птицы различают и нередко используют в качестве присах. При этом орлы в основном используют верхнюю перекламину метамической траверсы промежуточных опор (рис. 6).

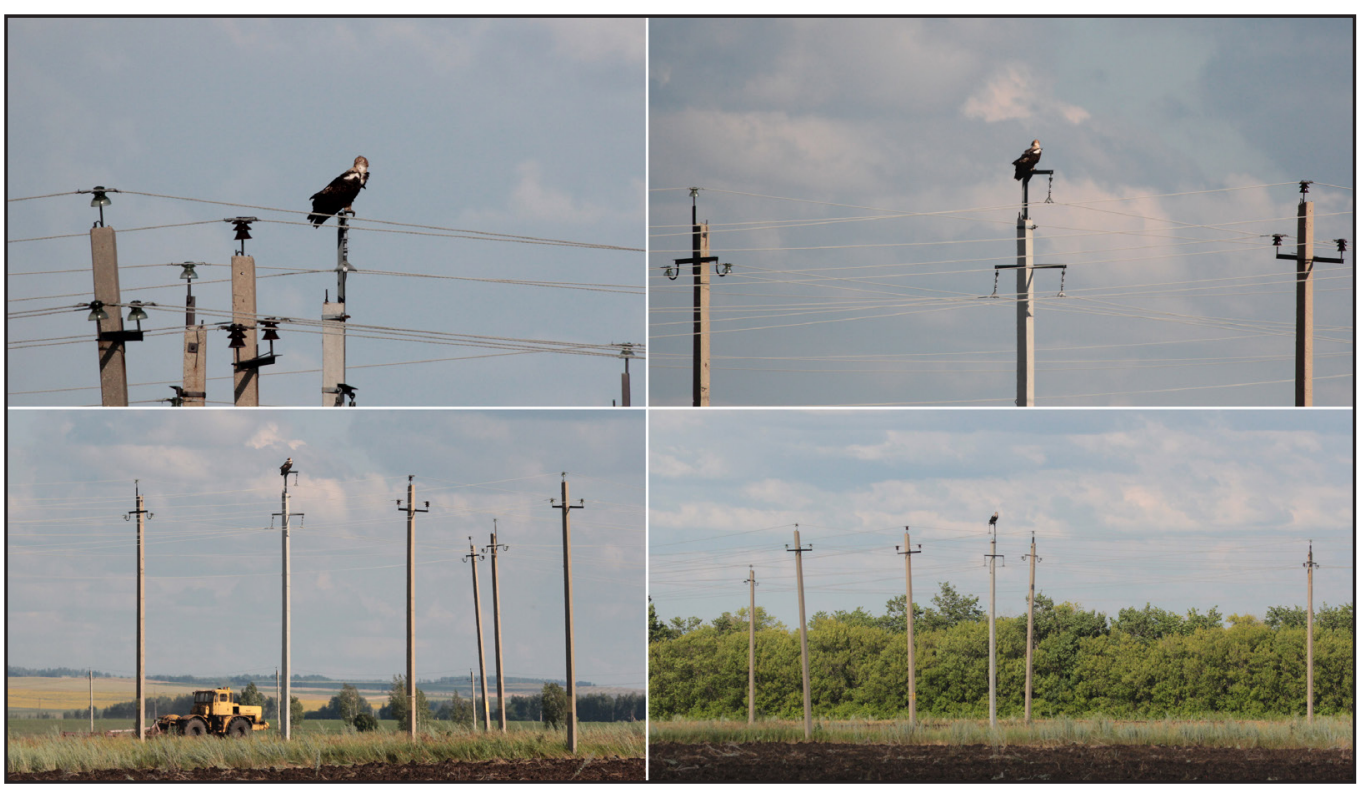


Рис. 8. Новый гнезАовой участок орла-могильника с гнездом на опоре АЭП высокого напряжения в Сармановском районе РТ. Фото Р. Бекмансурова.

Fig. 8. A new breeding territory of the Imperial Eagle with a nest on the pole of a high-voltage power line in the Sarmanovsky District of the Republic of Tatarstan. Photos by

R. Bekmansurov.

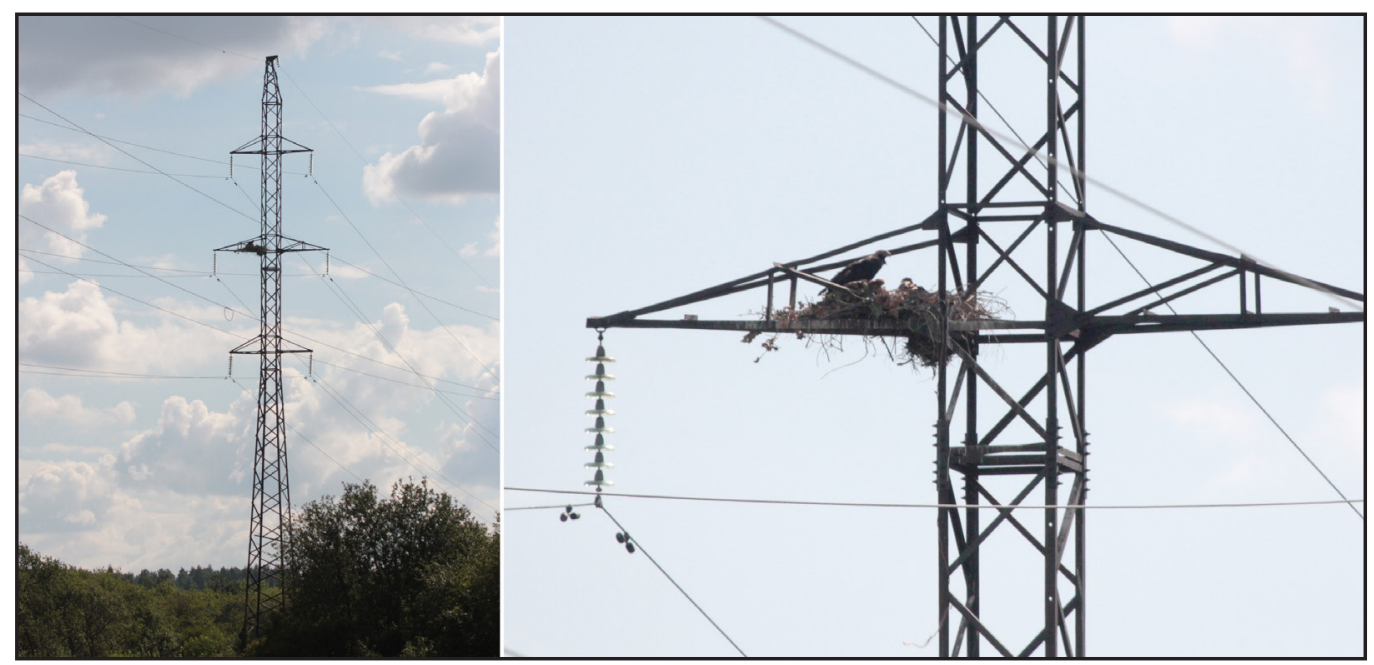

Нами проведено наблюдение взрослого орла-могильника 20.07.2020 г., который охотился вблизи своего гнезАового участка на полёвок в Сармановском районе Татарстана. В поле производилась вспашка и орёл следия за передвижением трактора, сидя на метамической траверсе с подвесными изоляторами оголовка железобетонной опоры ^ЭП 6 кВ, принамежашей неортяникам. Парамлемьно данной ^ЭП близко мруг от мруга находились ешё 4 ^ЭП такого же напряжения, но все они в конструкции оголовка имели штыревые изоляторы. Из 5 ^ЭП, расположенных парамельно, орёл выбрал наиболее безопасную (рис. 7).

С онной стороны, конструкция траверсы с подвесными изоляторами выглядит

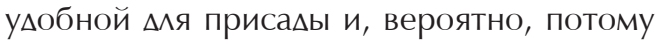
используется орлами. С мругой стороны может быть целенаправленное избегание опасных ^ЭП со штыревой изоляцией. Тем не менее, этот пример явно показывает избирательное поведение орлов в выборе более безопасной присады. Такое алаптивное поведение к электросетевой среде либо формируется на основе выбора привычных и удобных качеств присалы, мибо «сорормировано двумя основными фракторами: (1) частой гибемью птиц, не остерегаюшихся птицеопасных миний, и (2) орормированием у птиц стереотипного избегания таких миний, подьерживаемое отбором» (Шнайдер и мр., 2020). Аважды мы наблюдали взрослых орлов, подбираюших по опорами АЭП 6-10 кВ, погибших грачей. Кроме того, орлы нередко становятся свидетелями гибели мругих сородичей, в том числе своих птенцов.

Рост числа пар, гнездяшихся на опорах высоковольтных ^ЭП можно также отнести к алаптации к электросетевой среде и орормированию избирательного поведения.
В течение 2011-2015 гг. на юго-востоке Татарстана было выявлено 5 гнездо-

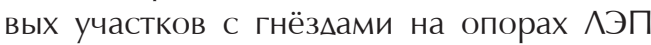
(Бекмансуров, 2015). В последуюшие годы выявлено ешё 3 гнездовых участка в Азнакаевском (2) и Сармановском (1) районах. Таким образом, адаптация орлов-могильников к электросетевой среде продолжается (рис. 8).

\section{II. Гибель орланов-белохвостов (Haliaee-}

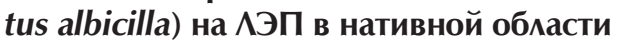

Попутно в ходе мониторинга гнездования орлана-белохвоста 17.07.2012 г. нами

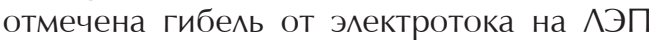
10 кВ молодого орлана на промежуточной опоре в $\Delta$ оь автодороги в поле в Спасском районе Татарстана, причём птица погибла

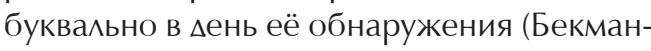
суров и мр., 2012a).

По результатам кольцевания птенцов орланов цветными кольцами и мечения GPS/ GSM-трекерами (Карякин и др., 2019; манные автора), их гибель на ^ЭП в нативной области не отмечена. Но орланы обитают в пределах Татарстана круглогодично, а зим-

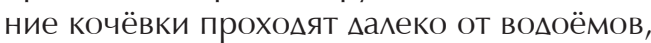
в том числе в неортегазодобываюших районах, нередко вблизи сельских населённых пунктов и полигонов твёрдых бытовых отходов, гле всегла имеются птицеопасные ^ЭП. Незначительное количество данных о гибели, скорее всего, связано с отсутствием постоянного мониторинга птицеопасных ^ЭП, в том числе вблизи гнездовых участков в первые месяцы после вылета птенцов. Так, 16.08.2019 г. во время осмотра известного гнездового участка ор^ана-белохвоста в Рыбнослободском районе Татарстана на расстоянии около 50 м от гнездового Аерева пол промежуточной опорой АЭП 6 кВ обнаружены останки с 


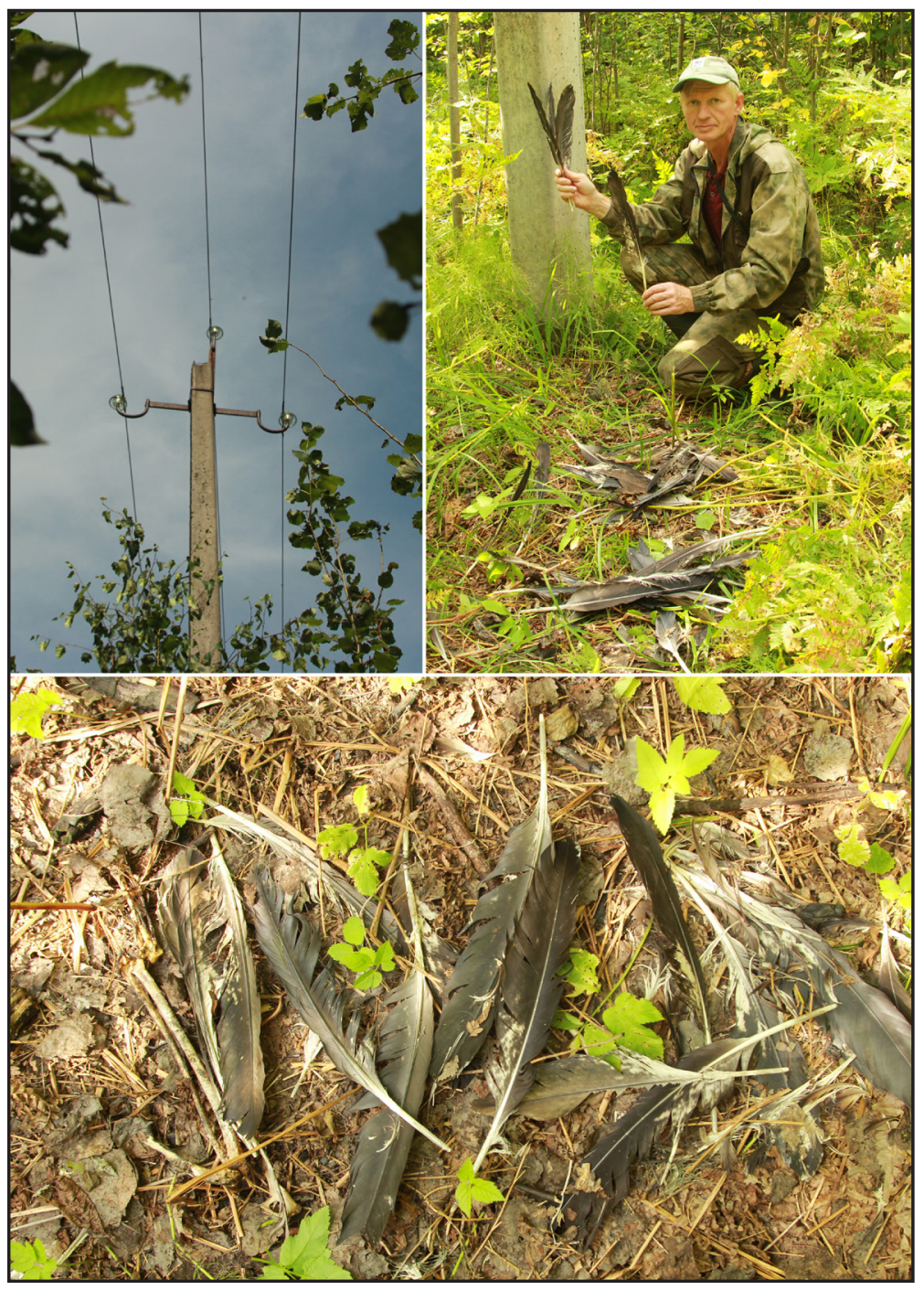

полным набором перьев молодого орланабелохвоста. По нераспавшимся пенькам определено, что останки приналлежами слётку, недавно покинувшему гнездо.

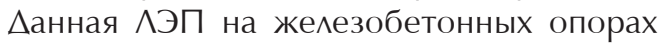
с креплением неизолированных прово$\Delta$ ов на штыревых изоляторах проходит по просеке через крупный ^есной массив в оОль берегового склона р. Камы. Ширина просеки около 10 м (рис. 9). Высо-

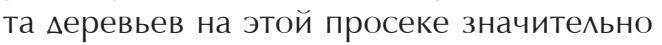
выше железобетонных опор, стандартная высота которых - 10 м. К примеру, высота гнездовой сосны - около 35 м с расположением гнезАа на его вершине. Почему слёток выбрал мля присады низкорасположенную железобетонную опору на узкой просеке при наличии высокоствольного меса, осталось невыясненным. Гибель птицы повлияла на установку пластиковых птицезашитных устройств на ближайшие

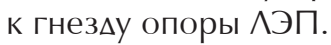

Вышеописанный случай показал, что молодые орланы также погибают в первые $\Delta н и$ и месяцы после вылета из гнёзь.
Рис. 9. Останки молодого орлана-белохвоста (Haliaeetus albicilla) под промежуточной опорой птицеопасной АЭП на лесной просеке 16.08.2019 г. в Рыбнослободском районе. Фото Н. Бекмансуровой.

Fig. 9. Remains of an immature White-Tailed Eeagle (Haliaeetus albicilla) under an intermediate pole of a power line dangerous for birds on a forest cleared strip on August 16, 2019, in Rybnoslobodsky District. Photos by N. Bekmansurova.

И их гибель возможна не только на АЭП, расположенных в открытых ^андшафртах, но и в глубине месного массива, на узких месных просеках. Аналогичный случай произошёл уже на следуюший гол в национальном парке «Нечкинский» в УАмуртии. 3Аесь в Костоватовском лесничестве 12 июля 2020 г. на узкой месной просеке были обнаружены сразу 2 трупа молодых орланов, также слётков, недавно покинувших гнездо. Слётки, судя по всему, яв^ямись сибсами и погибли практически одновременно на ближайших промежуточных опорах птицеопасной ^ЭП 6-10 кВ с железобетонными опорами и штыревой изоляцией. Тела птиц имели все признаки поражения электротоком, в том числе оборванную мапу у одной птицы. Также оста^ось невыясненным, что привлек^о молодых птиц на эту ^ЭП, так как она проходит посреди высокоствольного леса (рис. 10). В ходе следственных мероприятий, проведённых национальным парком, с экспертным заключением Союза охраны птиц России, влацельцев АЭП обязали провести птицезашитные мероприятия (см. сообшение на стр. 214-236).

Несмотря на малую выборку манных по гибели орланов-белохвостов, всё же можно слелать выво, что в первую очере $ь$, также как у орлов-могильников, гибнут молодые птицы.

Тем не менее, смертность орланов-белохвостов от электротока на АЭП 6-10 кВ ниже, чем у орлов-могильников. Это также подтвержАают результаты исследований по GPS/GSM-телеметрии 12 помеченных трекерами птенцов орланов. Их гибель на ^ЭП $\Delta$ о сих пор не отмечена. Возможно, это связано с тем, что гнездовые участки во всех случаях мечения были значитель-

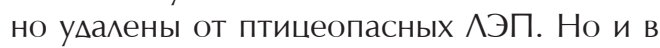
Аальнейших послегнезАовых перемешениях гибели на АЭП не выявлено.

Вызывает обеспокоенность в отношении орлана-белохвоста птицеопасная среда, созАаваемая АЭП 6-10 кВ на режимных объектах неортедобычи на искусственных дамбах 
Рис. 10. Осмотр трупов Авух молоАых орланов-белохвостов поА птицеопасной ^ЭП на ^есной просеке Костоватовского месничества сотрудниками национального парка «Нечкинский» в июле 2020 г. Фото из архивов национального парка «Нечкинский».

Fig. 10. Examination of the corpses of two immature White-Tailed Eagles under a power line dangerous for birds in the clear-cut strip of the Kostovatovsky Forestry by the staff of the Nechkinsky National Park in July 2020. Photos from the archives of the Nechkinsky National Park.

Рис. 11. Птицеопасная АЭП 10 кВ с промежуточной опорой, под которой обнаружен труп степного орла 05.06.2021 г. в Каракулинском районе УАмуртской Республики вблизи А. Чеганда. Фото М. Загумёнова.

Fig. 11. A $10 \mathrm{kV}$ power line dangerous for birds with an intermediate pole under which the corpse of the Steppe Eag le was found on June 5 2021, in the Karakulinsky District of the Udmurtian Republic near the village of Cheganda.

Photo by M. Zagumenov.

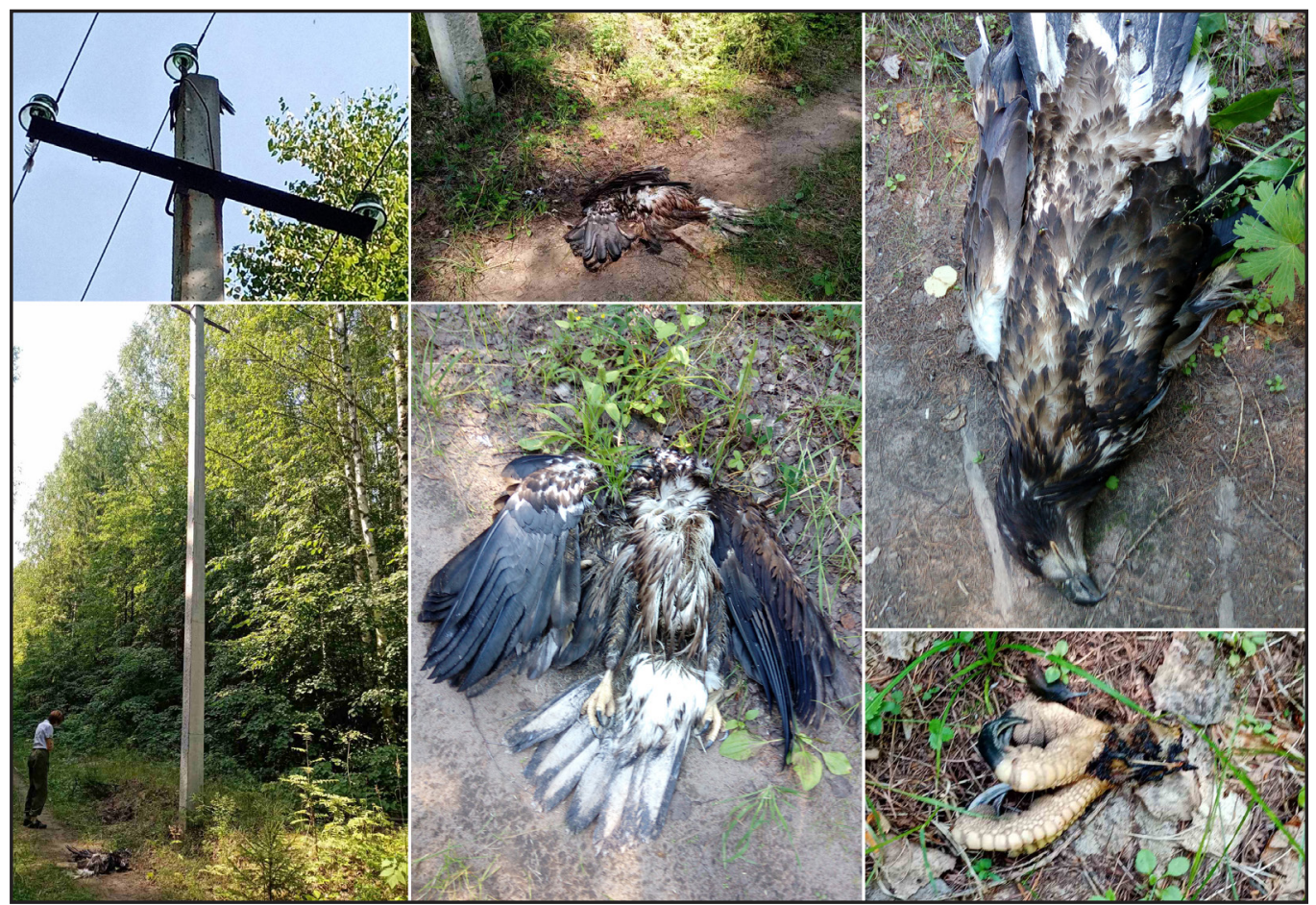

Нижнекамского водохранилиша, возле которых регулярно встречаются охотяшиеся птицы и откуда поступали сведения об их гибели.

По всей видимости, сеть птицеопасных АЭП Татарстана и сопредемьных регио-

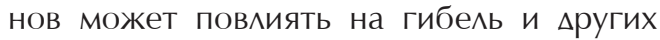
краснокнижных орлов, не гнездяшихся в Татарстане, редкие залёты которых возможны. Так, 05.06.2021 г. на сопрелельной территории в Каракулинском районе

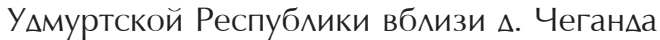

пол промежуточной опорой птицеопасной ^ЭП 10 кВ бы^ обнаружен труп степного орла (Aquila nipalensis) (М. Н. Загумёнов, мичн. сообш.). Владельцы АЭП наблюАателем не установлены, но это могут быть минии компании Роснеорть. Паралмельно по полю проходит ешё онна птицеопасная ^ЭП (рис. 11).

Залёт степного орла значительно севернее гнездового ареала сам по себе интересный и редкий фракт, но, к сожалению,

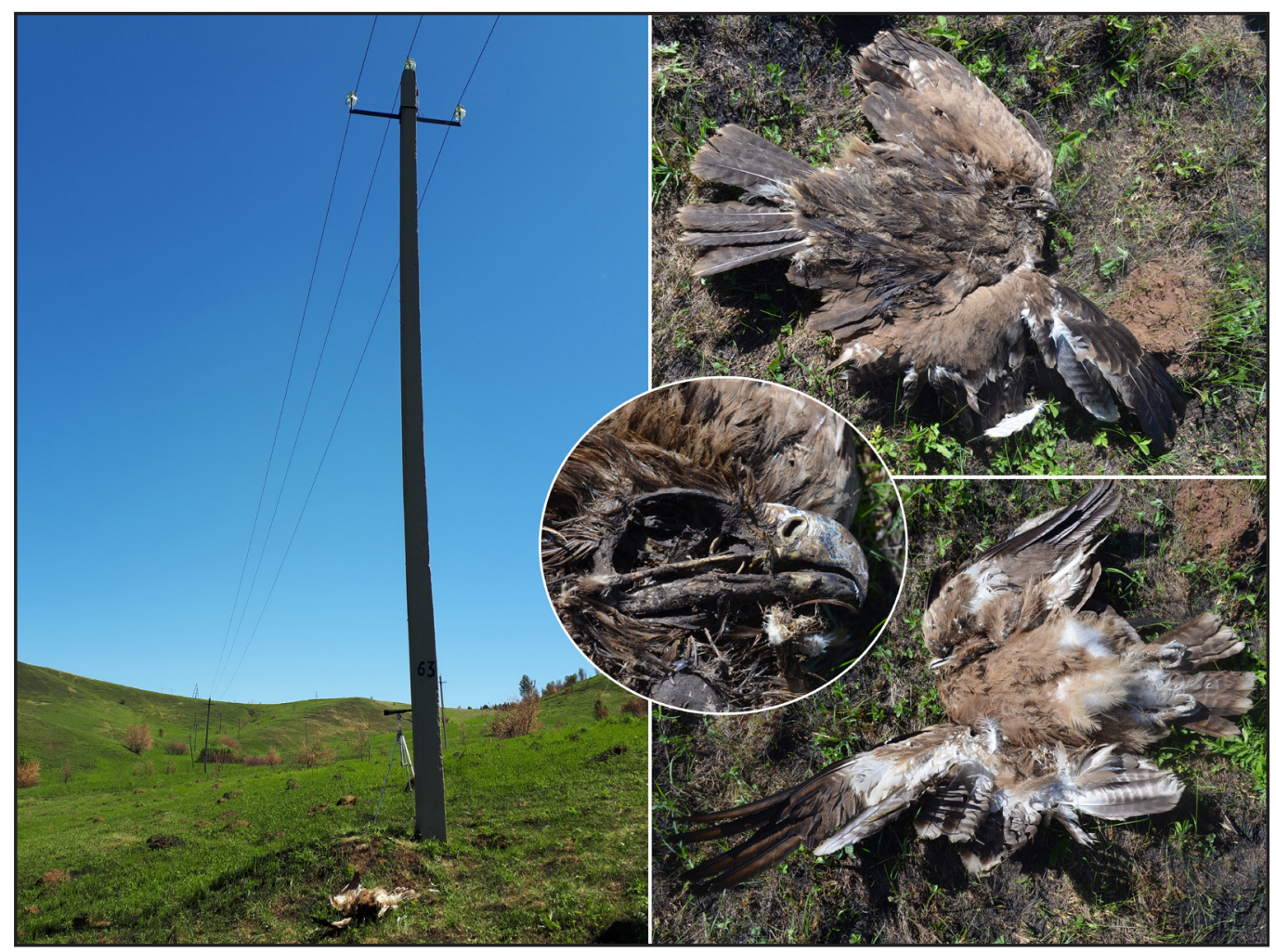


он закончился трагически Аля птицы. Степной орёл в степных регионах отмечен как

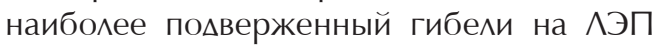
6-10 кВ среди Аругих видов орлов (Карякин, Новикова, 2006; Меджидов и мр., 2011; Карякин, 2012; Мацына и др., 2012; Аевин, Куркин, 2013; Пестов и мр., 2015).

\section{Проблемы мохернизашии АЭП 6-10 кВ}

В 2011 г., планируя масштабную работу по модернизации сушествуюших и недопушения строительства новых птицеопас-

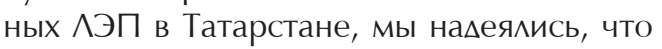
за 10 мет удастся Аостигнуть хороших показателей по зашите птиц от поражения электротоком, по крайней мере, в местах гнездования орлов и орланов. Крупные пернатые хишники, являясь своеобразными экологическими видами-зонтиками, также Аолжны были сыграть основную роль в зашите не только их самих, но и целого ряла Аругих птиц, находяшихся в постоянной зоне риска электросетовой среды. Но темпы модернизации АЭП оказались крайне низкими. К примеру, основ-

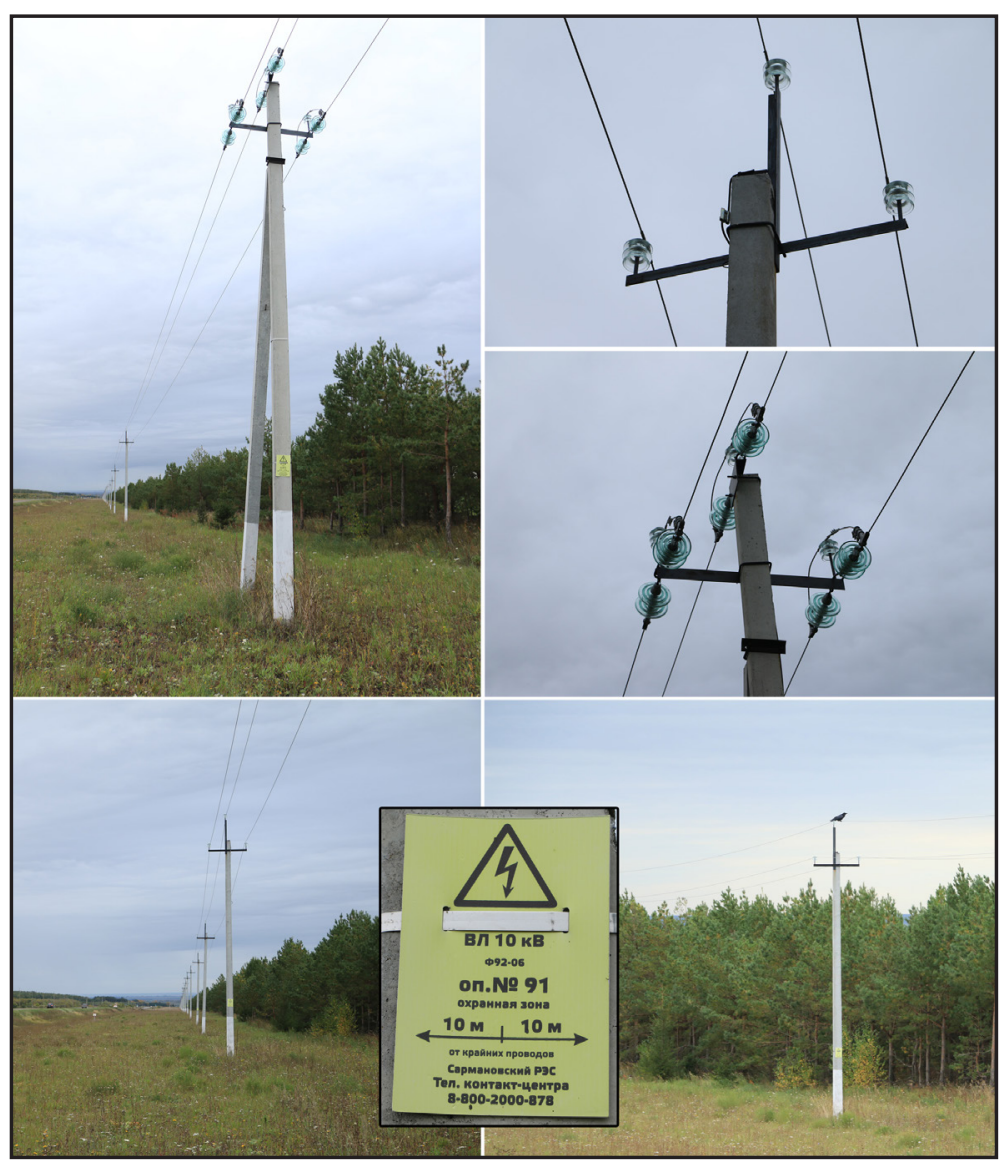

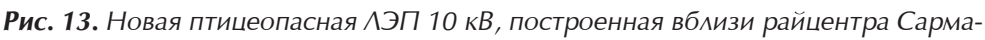
ново вАоль полигона ТБО, места сосредоточения птиц. Фото Р. Бекмансурова.

Fig. 13. A new $10 \mathrm{kV}$ power line dangerous for birds built near the district center of Sarmanovo along a solid waste landfill, a place where birds are concentrated. Photo by R. Bekmansurov.

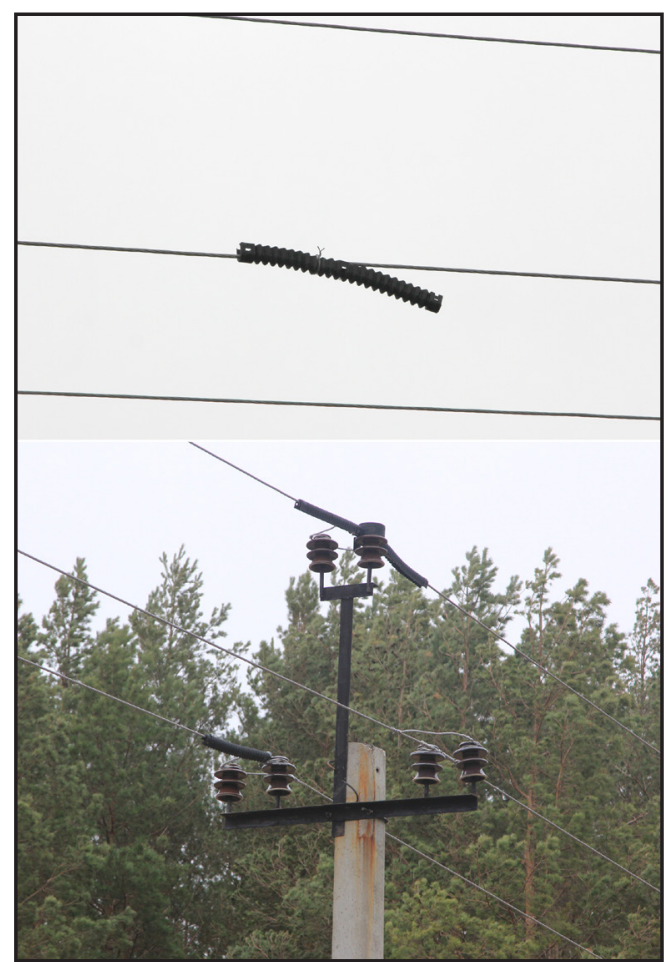

Рис. 12. Пример некачественного монтажа ПЗУ, приведший к их частичной потере (Елабужские ЭС). Закрепление пластикового кожуха алюминиевой проволокой является грубейшим нарушением технических требований монтажа, который может привести к гибели птиц. Фото Р. Бекмансурова.

Fig. 12. Example of poor-quality installation of BPDs, which led to their partial loss (Elabuga Power Grids). The plastic cover fixed with aluminum wire is a gross violation of technical installation requirements, which can lead to the death of birds. Photos by R. Bekmansurov.

ной владелец опасных $и я$ птиц АЭП в Татарстане ОАО «Сетевая компания» суше-

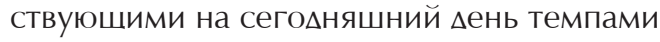
не сможет обеспечить безопасность птиц и за 20 последуюших лет. Ежегодные отчёты Сетевой компании по проведённым птицезашитным мероприятиям выглядят как тренировки персонала по монтажу пластиковых птицезашитных устройств. Так, нередко из всего фрилера, состояшего из Аесятков опор, пластиковые кожухи и колпаки ставятся на единицы опор, что не может обеспечить полную зашиту птиц. При проверках установки ПЗу выявлены нарушения в монтаже, неправильный подбор ПЗУ $А$ конкретного элемента оборудования, некачественное исполнение работ, маже случаи крепежа ПЗУ токопроводяшей алюминиевой проволокой (рис. 12). Некачественные работы приводят к быстрому разрушению ПЗУ и снижению сроков их службы. 


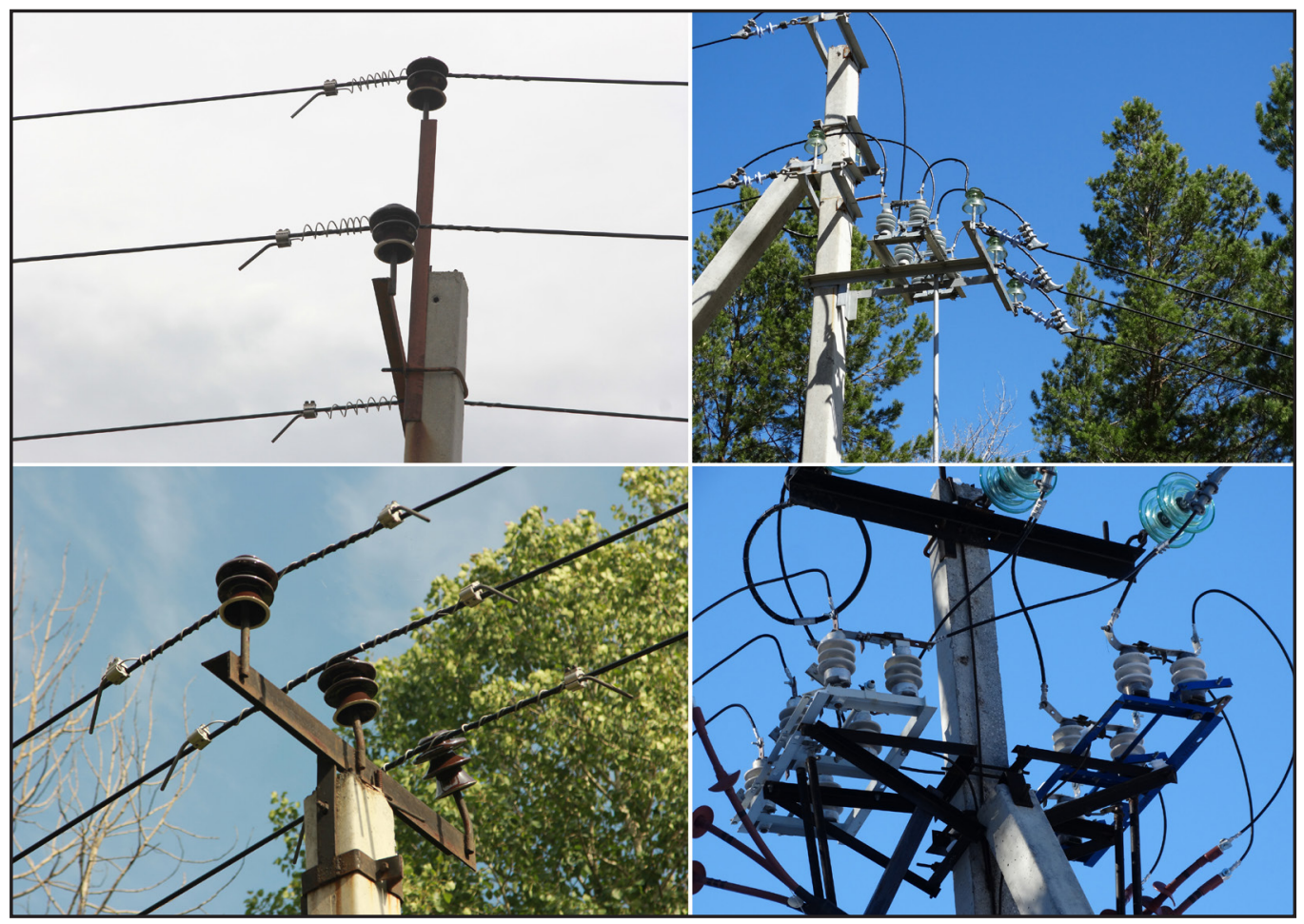

Рис. 14. Элементы грозозашиты без специальных ПЗУ на ВА 10 кВ с изолированным проводом (СИП-3): вверху слева - Фицер 6 пс/т Аружба АО Татавтодор в Мензелинском районе; внизу слева - ВА в Рыбнослободском районе в ^есном массиве запаннее пос. Берсут (собственник не установлен). Птицеопасные неизолированные

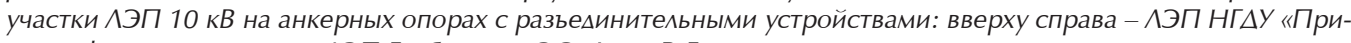
камнефть»; внизу слева - АЭП Елабужских ЭС. Фото Р. Бекмансурова.

Fig. 14. Elements of lightning protection without special BPDs on $10 \mathrm{kV}$ overhead lines with insulated wire (SIW-3): upper at the left - Feeder 6, transformer substation Druzhba of Tatavtodor JSC in Menzelinsky District; bottom at the left - overhead line in Rybnoslobodsky District in a forestland of the village of Bersut (the owner is not identified). Non-insulated sections of $10 \mathrm{kV}$ power lines on anchor poles with energy isolating devices that are dangerous for birds: upper at the right - power line of Prikamneft NGDU; bottom at the right - power line of Elabuga Power Grids. Photos by R. Bekmansurov.

Отмечены случаи строительства новых птицеопасных ^ЭП, что является показателем того, что проектные организации $\Delta о$ сих пор «выпускают» антиэкологичные проекты, не учитываюшие интересы сохранения биоразнообразия (рис. 13), а «Сетевая компания» не в полной мере отслеживает принятые стандарты по птицезашите.

Вызывает вопросы безопасности птиц применение в Татарстане самонесуших изолированных проводов (СИП-3), а именно наличие многочисленных точек выхода потенциала, в частности в местах расположения неизолированных токоведуших элементов грозозашиты (устройств зашиты от муги и мр.), прокалываюших зажимах, контактах на вводах в трансорорматоры, контактах реклоузеров и минейных разьединителей (рис. 14). Устанавливаемые на СИП-3 элементы грозозашиты без $\Delta$ ополнительного применения специальных ПЗУ также могут приводить к гибели птиц от электротока (Салтыков, 2020; Пестов и $\Delta$ р., 2020).
В течение последнего десятилетия мы наблюдали, как ПАО «Татнефрть» постепенно переводит АЭП 6-10 кВ с конструкций траверс со штыревой изоляцией на подвесную, которая, безусловно,

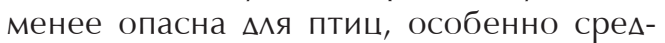
него и мелкого размера. Но у данных ^ЭП всегла остава^ись птицеопасные участки в виме траверс со штыревыми и натяжными изоляторами на анкерных опорах, в том числе на опорах с разъединительными устройствами; не применямись элементы изоляции на контактных выво $а$ ах трансорорматоров. К тому же нередко из-за занижения высоты провода наА землёй неортяники применями укороченную гирлянду изоляторов на промежуточных опорах, состояшую всего из одного изолятора тарельчатого типа, что может быть опасным $\Delta \wedge я$ крупных птиц, таких как орлы (рис. 15).

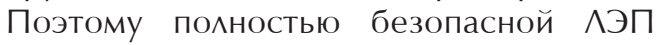
6-10 кВ с подвесной конструкцией изомяторов может стать только при зашите 
Рис. 15. АЭП 10 кВ ПАО «Татнефрть» С подвесными изомяторами (вверху); птицеопасный участок АЭП в виде траверсы со штыревыми и натяжными изоляторами на анкерной опоре и разьединительным устройством (внизу слева); орёл-могильник на верхней перекладине подвесной конструкции с укороченной гирлянАой на оголовке промежуточной опоры (внизу справа).

Фото Р. Бекмансурова.

Fig. 15. Power line $10 \mathrm{kV}$ of Tatneft PJSC with suspended insulators (upper); bird section dangerous for birds of the power line in the form of pin-type and stretching insulation on the anchor pole and energy isolating device (bottom at the left); Imperial Eagle on the top bar of the suspended structure with a shortened string on the head of the intermediate pole (bottom at the right). Photos by R. Bekmansurov.

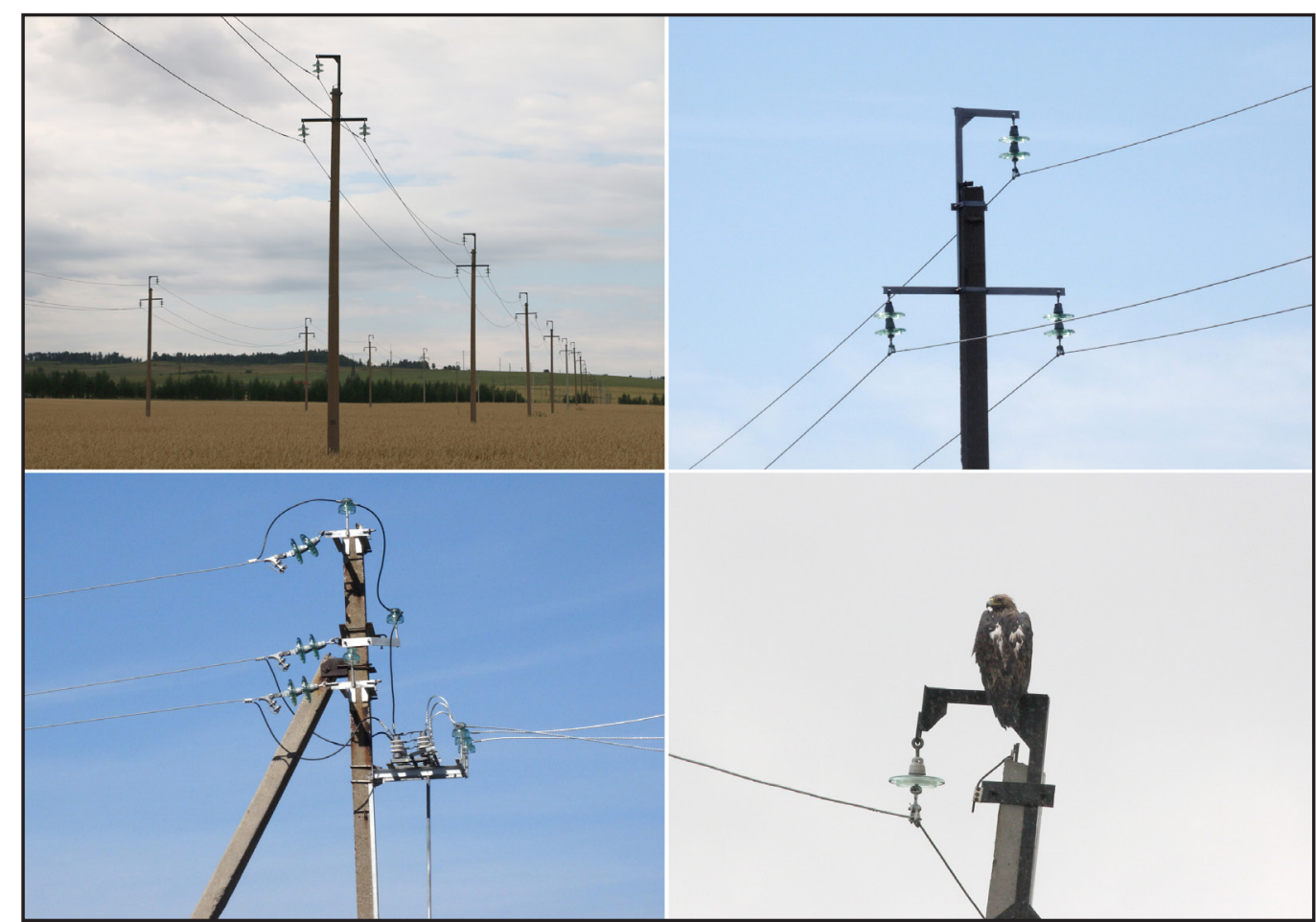

Аиэлектрическим материалом птицезашитных устройств сложных соединений проводов на угловых и анкерных опорах, включая разьединительные устройства и трансорорматоры, а также при установке миэлектрических кожухов вблизи изоляторов на промежуточных опорах.

Несмотря на перевод части ^ЭП на менее опасные $\Delta \wedge я$ птиц с подвесными изоляторами, у неортяников в Татарстане остаётся огромное количество птицеопасных ^ЭП 6-10 кВ со штыревыми изоляторами и голым проводом. Именно на них выявлены все случаи гибели орлов. В целом проблемы птицезашиты на ^ЭП оста^ись практически такими же, как и были 10 ^ет назаА (Бекмансуров, 2013).

\section{Заключение}

На территории Татарстана продолжается незаконная эксплуатация и даже

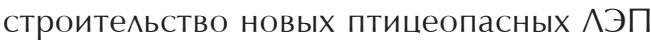
6-10 кВ. Несмотря на проводимые в республике меры по зашите птиц от гибеми в электросетевой среде, темпы и качество этих мероприятий таковы, что в ближайшем будушем ^ЭП будут влиять на смертность орланов и орлов в нативной области. А Аля такого вида как

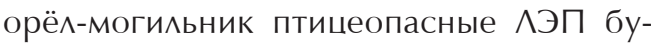
мут оказывать основное элиминируюшее воздействие.

Высокая смертность орлов, выявленная в юго-восточных районах Татарстана, гАе сосредоточен основной нефтяной промысел и, соответственно, повышенная птицеопасная электросетевая среда, указывает на необходимость направить повышенные усилия на проведение птицезашитных мероприятий в этих неортегазодобываюших районах. Основная смертность, выявленная мля молодых птиц-слётков в пределах гнездовых территорий, также указывает на необходимость комплексных птицезашитных мероприятий на всех типах птицеопасного оборудования в пределах не менее 3 км от центров гнездовых участков на начальных этапах проведения работ с последуюшим увеличением зон модернизации. Птицезашитные мероприятия не могут быть ограничены только лишь зонами вблизи гнезАовых участков, они Аолжны охватить все местообитания орлов, гАе могут погибнуть птицы в послегнездовое время и после возврата с зимовок.

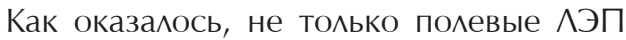
опасны мля орлана-белохвоста. Поэтому необходимо пересмотреть стратегию первоочередных птицезашитных мероприятий, и при на^ичии опасных АЭП на ^есных участках (просеках) вблизи мест гнездования включить их в планы первоочередных работ.

Гибель птиц на ^ЭП, Ааже таких крупных, как орлы, не всегла приводит к отк^ючению минии при коротком замыкании. Этот фракт необходимо учитывать при взаимодействии с собственникам ^ЭП при выяснении причин гибели птиц. 


\section{Благодарности}

Автор благодарит И.В. Карякина и А.В. Салтыкова за ценные дополнения при подготовке статьи. Особая благодарность ООО «Биосорера и технология», ООО «Горолская служба вывоза мусора» г. Подольск за материальную помошь $\iota \wedge я$ проведения полевых работ.

\section{Аитература}

Бекмансуров P.X. Сохранение популяций орлана-белохвоста, солнечного орла и большого подорлика на территории Республики Татарстан. - Российская сеть изучения и охраны пернатых ишников. 2012. [Bekmansurov R.H. Protection of Populations of the White-Tailed Eagle, Imperial Eagle and Greater Spotted Eagle in Republic of Tatarstan. - Russian Raptor Research and Conservation Network. 2012. (in Russian).] URL: http://rrrcn.ru/ru/archives/14163 Аата обрашения: 15.12.2021.

Бекмансуров Р.X. Проблемы и первый опыт организации зашиты птиц на воздушных линиях электропередачи в Республике Татарстан. - Oxрана птиц в России: проблемы и перспективы. Материалы Всероссийской научно-практической конференции с международным участием, посвяшенной 20-летию Союза охраны птиц России (Москва, 7-8 фревраля 2013 г.) / Отв. реА. Г.С. Ажамирзоев. Москва - Махачкала, 2013. C. 188-192. [Bekmansurov R.Kh. Problems and the first experience in the protection of birds on overhead power lines in the Republic of Tatarstan. - Problems and outlook of bird conservation in Russia. Proceedings of the All-Russian Conference, dedicated to the $20^{\text {th }}$ anniversary of Russian Bird Conservation Union (Moscow, 7-8 February 2013) / G.S. Dzhamirzoev (Ed.). Moscow - Mahachkala, 2013: 188-192. (in Russian).] URL: http://rrrcn.ru/ru/archives/19662 Аата обрашения: 15.12.2021.

Бекмансуров Р.Х. ААаптивные возможности орла-могильника при освоении АЭП Аля гнезАования в Республике Татарстан, Россия. Пернатые хишники и их охрана. 2015. № 31. C. 130-152. [Bekmansurov R.H. Adaptive Capabilities of the Eastern Imperial Eagle in Power Lines Exploration for Nesting Purposes in theRepublic of Tatarstan, Russia. - Raptors Conservation. 2015. 31: 130-152.] DOI: 10.19074/1814-8654-201531-130-152 URL: http://rrrcn.ru/ru/archives/26107 Аата обрашения: 15.12.2021.

Бекмансуров Р.Х., Аюпов А.С., Карякин И.В., Костин E.C. Результаты мониторинга гнездовых группировок орлана-белохвоста на некоторых особо охраняемых и прилегаюших к ним природных территориях в Республике Татарстан в 2012 году, Россия. - Пернатые хишники и их охрана. 2012. № 25. C. 79-96. [Bekmansurov R.H., Ayupov A.S., Karyakin I.V., Kostin E.S. Results of the Monitoring of the White-Tailed Eagle Populations in Some Protected Areas and Adjacent Territories in the Republic of Tatarstan in 2012, Russia.
- Raptors Conservation. 2012. 25: 79-96.] URL: http://rrrcn.ru/ru/archives/19107 Аата обрашения: 15.12.2021.

Бекмансуров Р.Х., Жуков А.В., Галеев А.Ш.Изучение гибели птиц на миниях электропередачи 6-10 кВ на территории Республики Татарстан с целью разработки поэтапного регионального плана по зашите птиц: предварительный анализ по итогам осенних исследований 2011 года. - Пернатые хишники и их охрана. 2012 b. № 24. C. 42-51. [Bekmansurov R.H., Zhukov D.V., Galeev A.Sh. Studying of Bird Electrocution on Overhead Power Lines 6-10 kV in the Territory of the Republic of Tatarstan to Develop the Step-bystep Regional Plan on Bird Protection: Preliminary Analysis of the Results of Autumn Surveys of 2011. - Raptors Conservation. 2012 b. 24: 42-51.] URL: http://rrrcn.ru/ru/archives/12291 Аата обрашения: 15.12.2021.

Бекмансуров Р.Х., Карякин И.В. Результаты мониторинга гнездовых группировок орла-могильника в Республике Татарстан в 2011-2012 гг., Россия. - Пернатые хишники и их охрана. 2013. № 26. C. 84-108. [Bekmansurov R.H., Karyakin I.V. Results of Monitoring of the Imperial Eagle Population in the Republic of Tatarstan in 2011-2012., Russia. - Raptors Conservation. 2013. 26: 84-108.] URL: http://rrrcn.ru/ru/archives/19595 $\triangle$ ата обрашения: 15.12.2021.

Бекмансуров Р.Х., Карякин И.В., Бабушкин М.В., Важов С.В., Аевашкин А.П., Пименов В.Н., Пчелинцев В.Г. Результаты работы Шентра кольцевания хишных птиц Российской сети изучения и охраны пернатых хишников в 2015 году. - Пернатые хишники и их охрана. 2016. № 33. C. 24-45. [Bekmansurov R.H., Karyakin I.V., Babushkin M.V., Vazhov S.V., Levashkin A.P., Pimenov V.N., Pchelintsev V.G. Results of work of the Raptor Ringing Center of the Russian Raptor Research and Conservation Network in 2015. - Raptors Conservation. 2016. 33: 24-45.] DOI: 10.19074/1814-8654-2016-33-24-45 URL: http:// rrrcn.ru/ru/archives/28148 $\triangle$ ата обрашения: 15.12.2021.

Бекмансуров Р.Х., Карякин И.В., Паженков А.С., Николенко Э.Г. Могильник в Республике Татарстан, Россия. - Пернатые хишники и их охрана. 2010. № 20. C. 119-127. [Bekmansurov R.H., Karyakin I.V., Pazhenkov A.S., Nikolenko E.G. The Imperial Eagle in the Republic of Tatarstan, Russia. - Raptors Conservation. 2010. 20: 119-127.] URL: http://rrrcn.ru/ru/archives/19254 Аата обрашения: 15.12.2021.

Карякин И.В. Проблема «Птицы и АЭП»: есть и положительный аспект. - Пернатые хишники и их охрана. 2008. № 12. C. 11-27. [Karyakin I.V. Problem «Birds and Power Lines»: Some Positive Effects Exist. - Raptors Conservation. 2008. 12: 11-27.] URL: http://rrrcn.ru/ru/archives/24950 $\triangle$ ата обрашения: 15.12.2021.

Карякин И.В. Пернатые хишники в эмектросетевой среде Северной Евразии: каковы перспективы выживания? - Пернатые хишники и их охрана. 2012. № 24. С. 69-85. [Karyakin I.V. 
Birds of Prey and Power Lines in Northern Eurasia: What are the Prospects for Survival? - Raptors Conservation. 2012. 24: 69-85.] URL: http:// rrrcn.ru/ru/archives/12320 Аата обрашения: 15.12.2021.

Карякин И.В., Бекмансуров Р.Х., Бабушкин М.В., Важов С.В., Бахтин Р.Ф., Николенко Э.Г. Шнайлер Е.П., Пименов В.Н. Результаты работы Центра кольцевания хишных птиц Российской сети изучения и охраны пернатых хишников в 2014 году. - Пернатые хишники и их охрана. 2015. № 30. C. 31-61. [Karyakin I.V., Bekmansurov R.H., Babushkin M.V., Vazhov S.V., Bachtin R.F., Nikolenko E.G., Shnayder E.P., Pimenov V.N. Results of work of the Raptor Ringing Center of the Russian Raptor Research and Conservation Network in 2014. - Raptors Conservation. 2015. 30: 31-61.] DOI: 10.19074/1814-8654-2015-30-31-61 URL: http://rrrcn.ru/ru/archives/25960 $\Delta$ ата обрашения: 15.12.2021.

Карякин И.В., Бекмансуров Р.Х., Горшков Ю.А. Первые результаты изучения миграций, зимовок и летних кочёвок молодых орланов-белохвостов из Татарстана с помошью GPS/GSMтрекеров. - Бутурлинский сборник: Материалы VI Межлународных Бутурлинских чтений. Ижевск: ООО «Принт», 2019. С. 152-159. [Karyakin I.V., Bekmansurov R.H., Gorshkov Yu.A. First results of studying migrations, wintering and summer movements of young White-Tailed Eagles from Tatarstan using GPS/GSM-loggers. - Buturlin Article Collection: Materials of the VI International Buturlin Readings. Izhevsk, 2019: 152-159. (in Russian).] URL: http://rrrcn.ru/wp-content/uploads/2019/12/Karyakim-etal-2019.pdf Аата обрашения: 15.12.2021.

Карякин И.В., Николенко Э.Г., Шнайдер Е.П., Бабушкин М.В., Бекмансуров Р.Х., Китель А.А., Пименов В.Н., Пчелинцев В.Г., ХАопотова А.В., Шершнев М.Ю. Результаты работы Центра кольцевания хишных птиц Российской сети изучения и охраны пернатых хишников в 2017 году. - Пернатые хишники и их охрана. 2018 а. № 37. C. 15-48. [Karyakin I.V., Nikolenko E.G., Shnayder E.P., Babushkin M.V., Bekmansurov R.H., Kitel D.A., Pimenov V.N., Pchelintsev V.G., Khlopotova A.V., Shershnev M.Yu. Results of Work of the Raptor Ringing Center of the Russian Raptor Research and Conservation Network in 2017. Raptors Conservation. 2018 a. 37: 15-48.] DOI: 10.19074/1814-8654-2018-37-15-48. URL: http://rrrcn.ru/ru/archives/31198 Аата обрашения: 15.12.2021.

Карякин И.В., Николенко Э.Г., Шнайдер Е.П., Хорват М., Проммер М., Юхаш Т., Паженков А.С., Зиневич А.С. Направление, характер и сроки миграции орлов-могильников из Волго-уральского региона и Русского А^тая (Россия) по Аанным GSM/GPS и Argos/GPS-телеметрии. Пернатые хишники и их охрана. 2018 b. Спецвып. 1. C. 140-143. [Karyakin I.V., Nikolenko E.G., Shnayder E.P., Horváth M., Prommer M., Juhász T., Pazhenkov A.S., Zinevich L.S. Direction, Nature and Timing of Migration of the Imperial Eagles from the Volga-Ural Region and Russian Altai (Russia) on Data of the GSM/GPS and Argos/GPS-telemetry. Raptors Conservation. 2018 b. Suppl. 1: 140-143.] URL: http://rrrcn.ru/ru/archives/32636 Аата обрашения: 15.12.2021.

Карякин И.В., Новикова А.М. Степной орём и инорраструктура ^ЭП в Западном Казахстане. Есть $л и$ перспектива сосушествования? - Пернатые хишники и их охрана. 2006. № 6. С. 48-57. [Karyakin I.V., Novikova L.M. The Steppe Eagle and power lines in Western Kazakhstan. Is coexistence have any chance? - Raptors Conservation. 2006. 6: 48-57.] URL: http://rrrcn.ru/ru/archives/31679 Аата обрашения: 15.12.2021.

Аевин А.С., Куркин Г.А. Масштабы гибели орлов на миниях электропередачи в Западном Казахстане. - Пернатые хишники и их охрана. 2013. № 27. С. 240-244. [Levin A.S., Kurkin G.A. The Scope of Death of Eagles on Power Lines in Western Kazakhstan. - Raptors Conservation. 2013. 27: 240-244.] URL: http:// rrrcn.ru/ru/archives/21230 Аата обрашения: 15.12.2021.

Аоктев В.Е., Федосюткин Б.А. Определение Аавности наступления смерти на месте происшествия (пособие мля оперативно-розыскных и следственных работников). - М.: УНПЬ ЮрИнороР. 1992. 32 с. [Loktev V.E., Fedosyutkin B.A. Determination of the prescription of death at the scene (manual for operational-search and investigative workers). - Moscow, 1992: 1-32. (in Russian).] URL: https://eg1lib.org/ book/2468910/012cf2?id=2468910 Аата обрашения: 15.12.2021.

Мацына А.И., Замазкин А.Е. Рекомендации по обеспечению безопасности объектов животного мира при эксплуатации воздушных миний связи и электропередачи на территории Нижегородской области. Нижний Новгород, 2010. 60 c. [Matsyna A.I., Zamazkin A.E. Recommendations on ensuring the safety of wildlife during the operation of overhead power and communication lines in the territory of the Nizhny Novgorod district. Nizhny Novgorod, 2010: 1-60. (in Russian).] URL: http://rrrcn.ru/ru/archives/12296 Аата обрашения: 15.12.2021.

Мацына А.И., Мацына Е.А., Корольков М.А., Бацмаев В.Э., Бацмаев В.Б. Оценка масштабов ежегодной гибели птиц в результате поражения электрическим током на воздушных миниях электропередачи 6-10 кВ в Калмыкии, Россия. - Пернатые хишники и их охрана. 2012. № 24. C. 186-201. [Matsyna A.I., Matsyna E.L., Korolkov M.A., Badmaev V.E., Badmaev V.B. Estimation of Sizes of the Annual Rate of Bird Mortality Caused by Electrocution on Power Lines 6-10 kV in Kalmykia, Russia. - Raptors Conservation. 2012. 24: 186-201.] URL: http:// rrrcn.ru/ru/archives/12386 Аата обрашения: 15.12.2021.

Мецжицов Р.А., Музаев В.М., Бацмаев В.Б. О состоянии популяции степного орла в Калмыкии. - Степной бюметень. 2011. № 32. 
C. 33-37. [Medzhidov R.A., Muzaev V.M., Badmaev V.B. On the state of the Steppe Eagle population in Kalmykia. - Steppe Bulletin. 2011. 32: 33-37. (in Russian).] URL: http://savesteppe.org/ru/ archives/6215 Аата обрашения: 15.12.2021.

Пестов М.В. Проблема «Хишные птицы и ^ЭП» на территории России. - Пернатые хишники и их охрана. 2005. № 4. С. 11-13. [Pestov M.V. The Problem of Raptors Electrocutions "Raptors and PowerLines" in Russia. - Raptors Conservation. 2005. 4: 11-13.] URL: http:// rrrcn.ru/ru/archives/31531 Аата обрашения: 15.12.2021.

Пестов. М.В., Онгарбаев Н.В., Смелянский И.Э., Аенисов $\triangle . А$. Факты гибели хишных птиц на воздушных миниях электропередачи, выполненных самонесушим изолированным проводом, в Западном Казахстане. - Пернатые хишники и их охрана. 2020. № 40. С. 52-62. [Pestov M.V., Ongarbayev N.Kh., Smelansky I.E., Denisov D.A. Deaths of Birds of Prey on Overhead Power Lines Made of Aerial Bundled Cables in Western Kazakhstan. - Raptors Conservation. 2020. 40: 52-62.] DOI: 10.19074/1814-8654-2020-4052-62 URL: http://rrrcn.ru/ru/archives/33714 $\Delta$ ата обрашения: 15.12.2021.

Пестов М.В., Сараев Ф.А., Терентьев В.А., Нурмухамбетов Ж.Э. Итоги проекта «Оценка влияния воздушных миний электропередачи средней мошности на орнитофрауну Мангистауской области (Республика Казахстан)». - Пернатые хишники и их охрана. 2015. № 31. С. 64-74. [Pestov M.V., Saraev F.A., Terentiev V.A., Nurmuhambetov Zh.E. The Project Outcome "Assessment of the Impact of Medium Voltage Power Lines on Avifauna in Mangistau Region (Kazakhstan)". - Raptors Conservation. 2015. 31: 64-74.] DOI: 10.19074/1814-8654-2015-31-64-74 URL: http:// rrrcn.ru/ru/archives/26094 Аата обрашения: 15.12.2021.

Салтыков А.В. К проблеме предотврашения гибели птиц от эмектрического тока на АЭП в Среднем Поволжье. - Тезисы докладов XXXII научно-технической конореренции. Часть 2 (1931 января 1998 года). УАьяновск: УАьяновский государственный технический университет, 1998. C. 63-64. [Saltykov A.V. On the problem of preventing the death of birds from electric current on power lines in the Middle Volga region. - Abstracts of the XXXII Scientific and Technical Conference. Part 2 (January 19-31, 1998). Ulyanovsk: Ulyanovsk State Technical University, 1998: 63-64. (in Russian).]

Салтыков А.В. Воздушные минии электропередачи 6-10 кВ как фрактор антропогенной элиминации птиц (итоги первых исследований в Волжско-Камском крае). - Труды УАьяновского научного центра «Ноосферные технологии». Том 2, выпуск 2. Умьяновск, 1999. С. 80-97. [Saltykov A. V. Overhead power lines 6-10 kV as a factor of anthropogenic elimination of birds (results of the first studies in the Volga-Kama region). - Proceedings of the Ulyanovsk Scientific Center "Noosphere Technologies". Volume 2, issue 2. Ulyanovsk, 1999: 80-97. (in Russian).] URL: http://rrrcn.ru/wp-content/uploads/2014/12/ saltykov-1.rtf Аата обрашения: 15.12.2021.

Салтыков А.В. О необходимости зашиты птиц на электросетевых объектах Республики Татарстан. - Актуальные экологические проблемы Республики Татарстан: Материалы IV республиканской научной конференции. Казань: Новое Знание, 2000. C. 76-77. [Saltykov A.V. On the need to protect birds at the power grid facilities of the Republic of Tatarstan. - Actual ecological problems of the Republic of Tatarstan: Materials of the IV Republican Scientific Conference. Kazan, 2000: 76-77. (in Russian).] URL: http://rrrcn.ru/wp-content/uploads/2014/12/saltykov-9.rtf Аата обрашения: 15.12.2021.

Салтыков А.В. Основы орнитологической безопасности электросетевой среды. - Бранта. 2014. Вып. 17. С. 153-160. [Saltykov A.V. Fundamentals of ornithological safety in the power grid environment. - Branta. 2004. 17: 153-160. (in Russian).] URL: https://branta.org.ua/branta-pdf/17/12_saltykov.pdf $\triangle$ ата обрашения: 15.12.2021.

Салтыков А.В. Современные В^З уничтожают птиц?! - Вести в электроэнергетике. 2020. № 3 (107). C. 68-73. [Saltykov A.V. Modern overhead power lines with protected wires destroy birds?! - Eelectric Power News. 2020. 3(107): 68-73. (in Russian).] URL: http://www. rbcu.ru/programs/313/36294 Аата обрашения: 15.12.2021.

Шнайьер Е.П., Николенко Э.Г., Карякин И.В. Гибель птиц на АЭП в Хакасии (Россия) в 2020 году. - Пернатые хишники и их охрана. 2020. № 41. C. 26-63. [Shnayder E.P., Nikolenko E.G., Karyakin I.V. Electrocutions of Bids on Power Lines in the Khakassia Republic, Russia, in 2020. - Raptors Conservation. 2020. 41: 26-63.] DOI: 10.19074/1814-8654-2020-41-26-63 URL: http:// rrrcn.ru/ru/archives/33844 Аата обрашения: 15.12.2021.

Lehman R.N., KennedyP.L., SavidgeJ.A. The state of the art in raptor electrocution research: a global review. - Biological Conservation. 2007. 136(2): 159-174. DOI: 10.1016/j.biocon.2006.09.015 URL: http://www.globalraptors.org/grin/researchers/uploads/531/global_review_2007.pdf $\triangle$ Ата обрашения: 15.12.2021.

LosS S.R., Will T., Marra P.P. Refining estimates of bird collision and electrocution mortality at power lines in the United States. - Plos One. 2014. 9(7): e101565. DOI: 10.1371/journal. pone.0101565 URL: https://journals.plos.org/plosone/article?id=10.1371/journal. pone.0101565 Аата обрашения: 15.12.2021.

Prinsen H.A.M., Boere G.C., Píres N., Smallie J.J. (Compilers). Review of the conflict between migratory birds and electricity power grids in the African-Eurasian region. CMS Technical Series No. XX, AEWA Technical Series No. XX. Bonn, Germany, 2011: 1-120. URL: https://www.cms.int/sites/ default/files/document/mop5_38_electr_review_ jkrev_0.pdf Аата обрашения: $15 . \overline{1} 2.202 \overline{1}$. 